\title{
Studeren voor nieuwe geleerden
}

Citation for published version (APA):

Gijselaers, W. H., \& Vermunt, J. D. H. M. (2000). Studeren voor nieuwe geleerden: over de kunst van het organiseren \$ Studeren voor nieuwe geleerden : over de kwaliteit van het leren. Universiteit Maastricht. https://doi.org/10.26481/spe.20001117wg

Document status and date:

Published: 17/11/2000

DOI:

$10.26481 / \mathrm{spe} .20001117 \mathrm{wg}$

Document Version:

Publisher's PDF, also known as Version of record

\section{Please check the document version of this publication:}

- A submitted manuscript is the version of the article upon submission and before peer-review. There can be important differences between the submitted version and the official published version of record.

People interested in the research are advised to contact the author for the final version of the publication, or visit the DOI to the publisher's website.

- The final author version and the galley proof are versions of the publication after peer review.

- The final published version features the final layout of the paper including the volume, issue and page numbers.

Link to publication

\footnotetext{
General rights rights.

- You may freely distribute the URL identifying the publication in the public portal. please follow below link for the End User Agreement:

www.umlib.nl/taverne-license

Take down policy

If you believe that this document breaches copyright please contact us at:

repository@maastrichtuniversity.nl

providing details and we will investigate your claim.
}

Copyright and moral rights for the publications made accessible in the public portal are retained by the authors and/or other copyright owners and it is a condition of accessing publications that users recognise and abide by the legal requirements associated with these

- Users may download and print one copy of any publication from the public portal for the purpose of private study or research.

- You may not further distribute the material or use it for any profit-making activity or commercial gain

If the publication is distributed under the terms of Article $25 \mathrm{fa}$ of the Dutch Copyright Act, indicated by the "Taverne" license above, 
216276373

Univorsite:tativilictivek

Universiteis Masastidit

ISBN 90-5681-098-7

(c) Wim Gijselaers, Maastricht 2000

(C) Jan Vermunt, Maastricht 2000 


\title{
Studeren voor Nieuwe geleerden: Over de kunst van het organiseren
}

\author{
Rede \\ In verkorte en vrije vorm uitgesproken bij de aanvaarding van het ambt \\ van hoogleraar Onderwijskunde aan de Faculteit der Economische \\ Wetenschappen en Bedrijfskunde van de Universiteit Maastricht \\ op vrijdag 17 november 2000 \\ Door \\ Dr. Wim Gijselaers
}


The art of progress is to preserve order amid change and to presenve change amid order

-Alfred North Whitehead 


\title{
Inleiding
}

\author{
Geachte Rector, \\ Dames en heren, \\ Beste Marjan, Maartje en Sybren,
}

Enkele maanden geleden vroeg een gewaardeerd collega mij waarom uitgerekend twee hoogleraren Onderwijskunde, ieder ook nog met een haast identieke leeropdracht, besloten hadden tot het houden van een dubbeloratie. Zijn boodschap was helder. Een dergelijke aanpak kon waarachtig geen leerzame middag worden. Naderhand bedacht ik dat er enkele oude onderwijskundige wetmatigheden bestaan, die bij zorgvuldige aanwending tot optimale leereffecten leiden. Wellicht ten overvloede wil ik ze toch even memoreren. De eerste leerwet behelst dat men slechts door veelvuldig repeteren leert en dus onthoudt. De tweede leerwet is dat die repetitie door variaties op een thema moet plaatsvinden.

Het College van Decanen moet op de hoogte zijn geweest over de potentielle kracht van deze simpele wetten, want anders valt het niet te verklaren waarom bij dubbeloraties de spreektijd met $1 / 3$ wordt teruggebracht tot dertig minuten terwijl de doelstellingen van de oratie ongewijzigd blijven. Tegen deze achtergrond verwacht $U$ uiteraard van mij, als hoogleraar Onderwijskunde, dat ik de meest recente inzichten uit mijn vakgebied zal toepassen teneinde de schade te beperken en er alsnog een leerzame aangelegenheid van te maken. Ik beloof dat ik mijn uiterste best zal doen. Maar ik wil op voorhand bij eventueel falen enkele verzachtende omstandigheden aandragen. In de eerste plaats is dit mijn eerste oratie, en volgens de eerste leerwet kan ik door gebrek aan repetitie de kunst van oraties nog niet volledig beheersen. Ten tweede, voorspelt de eerste leerwet, dat ik weliswaar iets van deze gelegenheid leer, maar door gebrek aan oefening, zal ik de kunst van oraties juist zelfs verleren. Vandaar dat ik het College van Decanen zou willen adviseren om ieder jaar voor alle hoogleraren een verplichte oratie van minstens een uur in te voeren. Dit komt niet alleen de kwaliteit van oraties ten goede, maar kan in het kader van docentenprofessionalisering ook de kwaliteit van de binnen universiteiten meest gebruikte onderwijsinnovatie verhogen; het zogenaamde hoorcollege. 


\section{Universiteiten En De Nultoestand}

Universiteiten in West-Europa en Noord-Amerika zijn de afgelopen dertig jaren in zwaar vaarwater terecht gekomen. Doemdenkers spreken zelfs over crisis en publiceren boeken met veelzeggende titels als "The Moral Collapse of the University" (Wilshire, 1990), en "The Monster Under the Bed" (Davis \& Botkin, 1994), of schrijven felle bijdragen in de pers met kopjes als "Where Universities Have Gone Wrong" (Piederit, 1996), "Universiteit moet Academie durven zijn" (Klamer, 2000) en "Academicus moet net zo vrij zijn als de rechter" (Cliteur, 2000). De voorzichtige optimisten prefereren meer hoopgevende titels als "Strategic Choices for the Academy" (Rowley, Lujan \& Dolence, 1997), en "A University for the $21^{\text {st }}$ Century" (Duderstadt, 2000). Ondanks hun tegengestelde opvattingen delen doemdenkers en optimisten tegelijkertijd een gemeenschappelijke zorg. Beide beschouwen wetenschap als een hoogwaardig cultuurgoed die ons kennis verschaft van natuurlijke en sociale verschijnselen. Beide zijn ook overtuigd van de noodzaak dat universiteiten een belangrijke rol spelen in de kennisinfrastructuur van de samenleving. Waar de meningen haaks op elkaar staan betreft het de vraag of universiteiten in hun huidige vorm nog blijven bestaan, of dat universiteiten hun strategische rol in de samenleving juist verder kunnen uitbouwen.

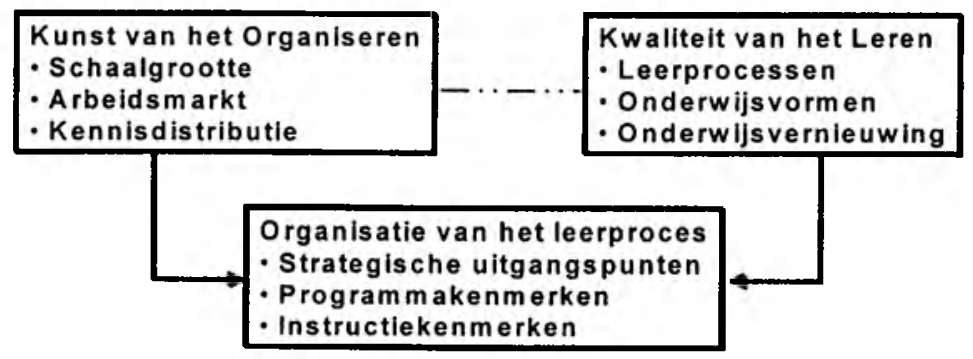

Figuur 1: De inhoud van deze dubbeloratie

Onlangs bepleitte Arjo Klamer (2000) nog dat aan de universiteiten alle praktijkgerichte opleidingen afgeschaft moesten worden. De universiteiten moesten terug naar hun oorspronkelijke missie: namelijk fungeren als klooster van deze tijd. Hij bepleitte een opzet van bachelors programma's, conform de opzet van Liberal Arts colleges in 
de VS. Studenten werken daar aan hun bachelorsgraad door kritisch te leren en systematisch na te denken. Doel van de BA is de ontwikkeling van algemene kennis, persoonlijke ontplooiing en het bijbrengen van maatschappelijk verantwoordelijkheidsbesef. Het leren van praktische kennis is van ondergeschikt belang. ${ }^{1}$ Pas na het krijgen van een 'brede vorming' mogen studenten verder voor een Masters waarmee ze dan wel opgeleid worden voor beroepen als advocaat, manager of dokter. Paul Cliteur (2000) was het op grote lijnen eens met K!amer, maar haastte zich om te melden dat Klamer te ver was doorgeschoten in zijn pogingen om praktische opleidingen taboe te verklaren. Rechten was immers een van de oudste academische disciplines, en stond in zeer hoog aanzien stond bij de klassieke academische denkers. Het werkelijke probleem zat volgens Cliteur minder in de academische discipline zelf, maar meer in "het feit dat bijna alle wetenschappen tegenwoordig de corrumperende invloed ondergaan van de vraag van de markt."

Klamer en Cliteur snijden in hun bijdragen twee essentiële vragen aan met betrekking tot wat voor een soort instelling een universiteit zou moeten zijn. Klamer legt vooral de nadruk op de zogenaamde academische vorming, terwijl Cliteur benadrukt dat de invloed van de buitenwereld op de academie zo minimaal mogelijk moet zijn. En beide zijn van mening dat universiteiten terug moeten naar hun oorspronkelijke missie. Dat laatste zou erop neer komen dat universiteiten zich moeten handhaven als kloosterachtige bolwerken van kennis, of om het meer bij de tijd te houden als kenniscentra die onafhankelijk zijn van externe invloeden.

$U$ begrijpt dat dit soort discussies niet ongemerkt aan mij voorbijgaan. Zeker niet omdat zij passen in een reeks van signalen die alle wijzen in de richting van veranderingen die binnen het hoger onderwijs zullen plaatsvinden. In deze oratie wil derhalve verkennen welke factoren daarin een rol spelen, en welke strategische en onderwijskundige opties voor de UM de komende jaren openstaan. In dat verband wil ik in deze oratie twee vragen centraal stellen:

- Welke externe factoren zijn van belang bij strategische heroriëntaties van universiteiten?

\footnotetext{
' Deze opvatting schijnt zelfs zo sterk ontwikkeld te zijn dat in een onderzoek van het Business-Higher Education Forum (1996) gerept wordt van regelrechte vijandigheid binnen de Liberal Arts Colieges tegenover de buitenwereld.
} 
- Welke onderwijskundige modellen zijn voor de UM denkbaar om één van haar academische kerntaken, namelijk het verzorgen van academisch onderwijs, te optimaliseren?

De laatste vraag zal vanmiddag, indachtig het belang van de eerste leerwet, twee keer aan de orde komen. Collega Jan Vermunt zal vanuit een leerpsychologisch perspectief ingaan op de vraag hoe in hoeverre het onderwijsmodel waarmee de Universiteit Maastricht faam heeft verworven, voldoet aan de eisen van het zogenaamde Nieuwe leren. Zelf zal ik dezelfde vraag aan de orde stellen door te verkennen welke factoren in de externe organisatie van de UM, noodzaken tot bijstelling van het Maastrichtse model. We vallen dus inderdaad in herhaling. Maar conform de eisen van de tweede leerwet is gekozen voor verschillende aanvliegroutes van deze problematiek. Mijn oratie zal in eerste instantie gericht zijn op een verkenning van de macroproblematiek, terwijl Jan Vermunt de microproblematiek zal verkennen.

\section{Studeren Voor Nieuwe Geleerden}

\section{Oude geleerden: Academische Vorming}

De vraag stellen naar Nieuwe geleerden, impliceert dat er zoiets bestaat als Oude geleerden. Laten we gemakshalve even veronderstellen dat de Oude geleerden geschoold werden vanuit de doelstellingen van de academische vorming. Meteen worden we dan geconfronteerd met universitaire tweespalt. Kessels (2000) is bijvoorbeeld van mening dat we dit soort doelstellingen in het museum van retorische uitspraken moeten plaatsen. Volgens hem is het nooit gelukt om handen en voeten te geven aan de doelen van academische vorming.

Enkele jaren geleden waagde Mirande (1995) een poging tot operationalisatie toen hij stelde dat studenten zich niet zouden moeten ontwikkelen tot wereldvreemde academici, maar tot kosmopolitische vertegenwoordigers van een vakgebied: tot doeners met wetenschappelijke diepgang met het vermogen om te reflecteren; tot denkers met praktisch inzicht met het vermogen om praktische problemen op te lossen; met oog voor de maatschappelijke context van hun vakgebied en voor de samenhang hiervan met andere vakgebieden. Het zal niet verbazen dat uit een recente studie van Nedermeijer en Vos (1999) blijkt dat docenten dit soort uitgangspunten volledig kunnen onderschrijven. Wat echter wel enigszins verbaasd is 
dat uit dezelfde studie blijkt dat juist op die punten waarin een academische opleiding zich zou kunnen onderscheiden van een hogere beroepsopleiding, vaak niet de afrondende stappen gezet worden om dit te realiseren. Het betreft dan vaardigheden zoals experimenteel denken, en het aanpakken van complexere problemen buiten de afbakening van afzonderlijke vakken. Hoewel het onderzoek van Nedermeijer en Vos (1999) slechts betrekking had op één studiejaar uit één studierichting, namelijk de propedeuse Scheikunde van de Universiteit Leiden, lijken de uitkomsten toch een teken aan de wand te zijn. Recent was een van mijn afgestudeerden, Esther Verboon, betrokken bij een meerjarig project ter bevordering van academische vorming binnen de opleidingen van de Universiteit Utrecht. Het verbeteren van de onderwijskundige condities voor verwerving en toetsing van academische vorming stond in dit project centraal (Oost, Holleman, van den Berg, Thoolen, \& Milius, 1998; Verboon, 1999). Een van de uitkomsten van dit project is dat een profiel voor de academicus in de 21 ste eeuw is ontworpen waaraan elke afgestudeerde, onafhankelijk van de gevolgde studierichting, zou moeten voldoen (Holleman, van den Berg, Oost, Thoolen, \& Admiraal, 1998). Verboon (1999) kwam tot de conclusie dat een dergelijk profiel als stapelprofiel getypeerd zou mogen worden. Volgens haar kon een academisch profiel als volgt getypeerd worden: "studenten moeten (wetenschappelijke) kennis verwerven, moeten met behulp van die kennis vaardigheden ontwikkelen en die kennis en vaardigheden kunnen toepassen in specifieke (wetenschappelijke) beroepssituaties, ofwel als academicus competent zijn. Tevens moet deze expertise zijn ingebed in een academische habitus, waarvan eén van de meest opvallende kenmerken is dat de academicus niet alleen oog heeft voor (inter)nationale wetenschappelijke ontwikkelingen maar vooral ook brede maatschappelijke en culturele betrokkenheid betoont."

$U$ begrijpt, ik kan niet tegen een dergelijk profiel zijn. En ik vermoed dat Arjo Klamer en vele anderen dergelijke doelstellingen van universitair onderwijs alleen maar van harte kunnen onderschrijven. Maar hebben we daarmee dan ook een oplossingen gevonden voor de vraag hoe we onze studenten op een zodanige manier onderwijs kunnen geven teneinde dat ze aan deze doelstellingen voldoen? En weten we ook of de samenleving behoefte heeft aan dergelijke afgestudeerden?

\section{Nieuwe Geleerden}

Haaks op het universitaire streven naar academische vorming staan pogingen vanuit bedrijfsorganisaties om curricula van het hoger 
onderwijs te veranderen. Voorbeelden daarvan zijn onder andere te vinden in de Verenigde Staten in publicaties van het Business-Higher Education Forum en de Boyer Commission (1998). In een rapport van de Business-Higher Education Forum (1996) wordt een vergelijkbare conclusie getrokken wat betreft de vormingsdoelstellingen van Liberal Arts Colleges: "Although the value of liberal arts is cited repeatedly by people at different levels in all institutions, there is little agreement on what constitutes the liberal arts or specificity about what outcomes should result."

In een vervolg op dit rapport heeft het Business-Higher Education Forum (1999) ideeën gepresenteerd hoe studenten in de Verenigde Staten beter door universiteiten voorbereid kunnen worden op hun werkplek. Uitgangspunt was dat door de snelle veranderingen in de economie, voortdurend veranderingen plaatsvinden op de werkplek. Tegelijkertijd werd geconstateerd dat universiteiten grote moeite hebben om studenten adequaat op deze veranderingen voor te bereiden. In dit rapport wordt de conclusie getrokken dat afgestudeerde studenten over vaardigheden moeten beschikken wat betreft communicatie, probleemoplossen en zelf-management, het vermogen om analytisch te kunnen denken, en besef hebben van de problematiek van globalisering. Tegen deze achtergrond is men van mening dat het hoger onderwijs niet langer exclusief gericht kan zijn op de verwerving van kennis. Men bepleit dan ook dat het hoger onderwijs naar nieuwe onderwijsvormen zoekt, en naar nieuwe wegen om een sterker verband te leggen tussen externe, economische, verandering en de interne organisatie van het hoger onderwijs.

Vanuit de Ondenwijskunde zijn recent ook aanzetten gegeven tot verandering (bijvoorbeeld Simons, Van der Linden \& Duffy, 2000). Vanuit dit vakgebied bepleit men dat nieuwe vormen van leren noodzakelijk zijn omdat het onmogelijk is om studenten kennis van een vakgebied, met de daarbij behorende vaardigheden, bij te brengen waarmee ze de rest van hun leven een beroep kunnen uitoefenen. Het Studiehuis en de Basisvorming kunnen in deze context ook als poging beschouwd worden om leerlingen de noodzakelijke vaardigheden bij te brengen om op een andere manier met kennis om te gaan.

Los van de vraag welke opvatting uiteindelijk zijn meerwaarde zal tonen, blijkt uit bovenstaande dat bestudering van leerprocessen en de daarmee beoogde leerresultaten, van wezenlijk belang is om plaats en functionaliteit van het hoger onderwijs te bepalen. Om een scherper beeld te krijgen van het onderscheid tussen de Oude en Nieuwe 
geleerden is het noodzakelijk om kort een historische schets van universiteiten te geven.

\section{De Universiteit Als Toegangspoort Tot Kennis}

\section{De Docerende Universiteit}

De universiteit is altijd een plaats geweest waarin kennisproductie, kennisverspreiding en kennisopslag centraal stonden en waardoor zij belangrijke maatschappelijke en culturele functies uitoefende (Noam, 1995; Duderstadt, 2000). Daarin zijn universiteiten de afgelopen negenhonderd jaar buitengewoon effectief geweest. Juist door haar eigen koers te bewandelen, wars van alle modernismen, fungeert zij nog altijd als kenniscentrum met een eigen identiteit. Dat betekent echter niet dat geen veranderingen hebben plaatsgevonden. Integendeel. Kenners van de universitaire geschiedenis maken normaliter onderscheid in drie tijdvakken waarin relatief grote veranderingen hebben plaatsgevonden (Davis \& Botkin, 1994; Bowden \& Marton, 1998).

De eerste periode loopt vanaf de Middeleeuwen tot aan het begin van de industriële revolutie. Daarin bieden universiteiten een beperkt aantal disciplines aan die vooral gericht zijn op academische vorming. Ontwikkeling van kritisch denken staat centraal, en universiteiten worden als bolwerken van kennis gezien. Kennis is tegelijkertijd een schaars goed dat bescherming behoeft tegen de buitenwereld. En dus ontwikkelt zich in de periode een universitair monopolie op de toegankelijkheid en productie van kennis (Salomon, 1999). Het is slechts toegankelijk voor de enkeling die bereid is om naar kloosterachtige instituten af te reizen op zoek naar welwillende leermeesters. De middeleeuwse universiteit wordt vaak beschouwd als een docerende universiteit. Kennis ligt namelijk grotendeels besloten in docenten, en studenten kunnen zich die eigen maken door te luisteren naar hun leermeester.

\section{De Onderzoekende Universiteit}

De tweede periode valt samen met het begin van de Industriële Revolutie in de Negentiende Eeuw. Er ontstaat een groeiende maatschappelijke vraag naar toegepaste of professionele kennis. De natuurwetenschappen komen tot bloei en eisen hun plaats binnen de universiteit op. In die periode verandert het karakter van universiteiten 
door de ontwikkeling van de zogenaamde 'Onderzoeksuniversiteiten'. In Duitsland ontwikkelt Wilhelm von Humboldt (1809) de idee van de zogenaamde "Universitas litterarum" en beïnvloed daarmee de vormgeving van onderzoeks-universiteiten waarin studenten Lernfreiheit krijgen, en de docenten Lehrfreiheit. De eenheid van onderzoek en onderwijs komt centraal te staan om studenten een omvattende humanistische vorming te bieden. Beide krijgen de vrijheid om zelf keuzes te maken in hun leer- en onderzoeksproces, en beide staan voor de taak om nieuwe kennis te ontwikkelen. De wetenschappelijk staf staat niet ten dienste van studenten, maar ze moeten beide een onderzoeksgemeenschap vormen. Onderzoek is in die optiek de primaire taak van de universiteit, en onderwijs de afgeleide daarvan. De gedachte is dat onderzoek als het ware de motor vormt voor het genereren van nieuwe kennis, en dat het onderwijs daarmee zijn voordeel doet. Goed onderzoek leidt tot goed onderwijs en niet andersom. Opvallend is dat de zogenaamde Lehrfreiheit (of Academische Vrijheid) tot een van de belangrijkste culturele waarden van de universiteit is uitgegroeid, tenwijl de Lernfreiheit steeds meer naar de achtergrond verdwenen is. In dezelfde periode vallen echter ook andere geluiden te horen. Newman (1853) schrijft in zijn "The Idea of a University" dat: "... to discover and teach are distinct functions; they are also distinct gifts, and are not commonly found united in the same person."

\section{De Geleerde Universiteit}

De derde periode treedt na de Tweede Wereldoorlog op. Universiteiten veranderen van elite-instellingen tot organisaties die geconfronteerd worden met een massale studenteninstroom, afnemende steun van de Overheid, toenemende kritiek op de kwaliteit van het onderwijs, en restricties in onderzoeks- en studiefinanciering. Tegelijkertijd hebben universiteiten hun onderzoeksinspanningen (in termen van personeelsinzet) sterk weten te verhogen, is de productie van wetenschappelijke artikelen fors toegenomen, en zijn getalsmatig meer studenten dan ooit afgestudeerd. De afgelopen dertig jaren is bijvoorbeeld in de VS de studenteninstroom toegenomen van 3 miljoen

\footnotetext{
${ }^{2}$ Recent onderzoek van Feldman (1987) en Hattie en Marsh (1996) laat zien dat Newman (1853) waarschijnlijk meer gelijk had dan Von Humboldt. In beide publicaties worden meta-analyses beschreven die beide in dezelfde richting wijzen: "We must conclude that the common belief that research and teaching are inextricably intertwined is an enduring myth. At best, research and teaching are very loosely coupled (Hattie \& Marsh, 1996, p. 529)."
} 
in 1960 tot.15 miljoen in 1995. Tegenwoordig begint in de VS meer dan vijttig procent van de High School afgestudeerden aan een of andere vorm van hoger onderwijs (Boyer Commission, 1998). Vergelijkbare fenomenen doen zich voor aan de West-Europese universiteiten. En wie het niet gelooft mag zichzelf op de hoogte stellen van de uitpuilende collegezalen in landen als Duitsland en Oostenrijk.

Dergelijke ontwikkelingen zouden als een zegen voor de samenleving beschouwd mogen worden. Of zoals Salomon (1999) recent opmerkte: "Bestofte, elitaire en besloten universiteiten gooien eindelijk hun deuren open, zodat iedereen gelijke, democratische en gemakkelijke toegang kan krijgen tot het hoger onderwijs. Uit het ooit bevoorrechte bolwerk sijpelt informatie nu rechtstreeks de huizen van iedereen die kennis zoekt." Maar in dat laatste lijkt nu net het probleem te schuilen. Universiteiten worden door rijksoverheden steeds meer beschouwd als motor, of economische factor, om bestaande economische structuren te transformeren naar moderne op technologie gebaseerde kenniseconomieën: "Education is the crucial element in this transformation process. It can no longer be considered apart from the state's overall economic strategies" (Marshall, 1995, cit in Alexander 1999). Hoger onderwijs vormt in dat geheel een belangrijke factor tot toekomstig succes. In de Economist (1997) werd volgens Alexander (1999) onlangs het standpunt verkondigd dat: "In such an economy one in which ideas, and the ability to manipulate them, count for far more than the traditional factors of production- the university has come to look like an increasingly useful asset".

Ondanks het belang dat aan hoger onderwijs wordt toegekend als economische motor, kan tegelijkertijd een tegenstrijdigheid gesignaleerd worden. ${ }^{3}$ Universiteiten in de Verenigde Staten en West Europa krijgen steeds minder publieke steun als de verdeling van middelen betreft (Rowley, Lujan, \& Dolence, 1998).

\section{Politieke omgeving}

Als we naar de Nederlandse situatie kijken dan schetst de rijksoverheid een beeld waarin het betrekken van universiteiten in nieuwe

\footnotetext{
${ }^{3}$ Management goeroe Peter Drucker (in Lenzer, \& Johnson, 1997) is trouwens van mening dat: "Thirty years from now the big university campuses will be relics. Universities won't survive. It's as large a change as when we first got the printed book." Hij stoelt zijn mening op het feit dat universiteiten hun monopoliepositie op kennis verloren hebben en niet kunnen inspelen op veranderingen in de markt.
} 
kennisinfrastructuren van groot belang wordt geacht (Kennis is Kracht, 2000). Toch werpt een recent rapport (Wetenschapsbudget 2000, Wie oogsten wil moet zaaien) van het Ministerie van OCenW een ander licht op de zaak. Ik citeer letterlijk uit het rapport (pagina 7) de volgende conclusies:

- "De rijksbijdrage die de rijksoverheid rechtstreeks betaalt aan de universiteiten, daalt in reële termen al geruime tijd. Desondanks hebben de universiteiten hun onderzoeksinspanningen (in termen van personeelsinzet) tot 1994 sterk weten te verhogen. Vanaf dat jaar toont de onderzoekinzet echter een gestage daling, bij een vrijwel constante productie van wetenschappelijke artikelen."

- "De tweede geldstroom, is de laatste jaren constant gebleven. Deze geldstroom is relatief klein ten opzichte van de eerste."

- "De derde geldstroom is vanaf 1980 sterk gestegen, deze omvat nu $27 \%$ van het wetenschappelijk personeel, en ongeveer $20 \%$ van de onderzoekmiddelen van de universiteiten. ... Het aandeel van het bedrijfsleven in het contractonderzoek van de universiteiten (in 1996 $17 \%$ ) daalt, evenals het absolute bedrag."

Naast afnemende publieke steun voor de financiering van universiteiten kan aan de andere kant geconstateerd worden dat door veranderingen in de regelgeving (waaronder de invoering van de Bachelors / Mastersstructuur), de bestuurlijke druk op universiteiten toeneemt.

\section{De UM in de 21ste eeuw}

De invloed van historische en politieke factoren kan uiteraard niet onderschat worden. Maar ik wil me concentreren op factoren die beter manipuleerbaar zijn. Ik wil mijn analyse starten op basis van een aantal uitgangspunten. In de eerste plaats beschouw ik een universiteit als een intellectueel organisme dat deel uitmaakt van een bepaald ecosysteem. In de tweede plaats moet gezocht worden naar een ecosysteem waarin eventuele effecten van veranderingen macroscopisch observeerbaar zijn. In de derde, en tevens laatste plaats, moet dit ecosysteem zich op een veilige afstand van de waarnemer bevinden, teneinde bij eventuele risico-situaties een veilig heenkomen te vinden.

Een dergelijke analyse kan uiteraard slechts plaatsvinden door de ons welbekende UM, onder voorzitterschap van D., tot object van een casusstudie te maken. In de analyse van het functioneren van het eco- 
systeem ${ }^{4}$ zullen vervolgens drie marktfactoren betrokken worden: 1) schaalomvang van universiteiten, 2) veranderingen op de werkplek en arbeidsmarkt, en 3) de rol van kennisproducenten en kennisdistributeurs. Aangezien we te maken hebben met een situatie waarin sterke veranderingen optreden zal getracht worden om inzicht te krijgen in bepaalde trends, en de vraag of tekenen van trendbreuk zichtbaar zijn. Interpretatie van de uitkomsten van de analyse moet uiteraard met de nodige voorzichtigheid gebeuren, vandaar de subtitel van deze oratie dat het hier om een kunst gaat en minder om een kunde.

Het zal duidelijk zijn dat we met het organisme doelen op de University of Michigan, die tot voor kort onder voorzitterschap stond van James J. Duderstadt. ${ }^{5}$ Het eco-systeem verwijst naar de situatie in de VS. Om enige referentiepunten te geven zullen ter vergelijking ook enkele basisgegevens van de Universiteit Maastricht genoemd worden.

\begin{tabular}{lrr}
\hline 1999 & UM, Ann Arbor $^{6}$ & UM, Maastricht $^{7}$ \\
\hline Ingeschreven Studenten & 37846 & 10688 \\
$\begin{array}{l}\text { Personeel } \\
\text { WP }\end{array}$ & 4281 & 1053 \\
$\begin{array}{l}\text { Overheidsbijdrage (State + Federal) } \\
\text { (excl. Academische Ziekenhuizen) } \\
\text { ITotale baten }\end{array}$ & $43 \%$ & $61 \%$ \\
$\begin{array}{l}\text { Rangorde } \\
\text { Business Programma } \\
\text { MBA }\end{array}$ & & \\
\end{tabular}

De University of Michigan werd in 1817 opgericht als een Public State University. Naast de hoofdcampus op Ann Arbor (inclusief academische ziekenhuizen), bezit deze universiteit meerdere kleine campussen en

\footnotetext{
${ }^{4}$ Binnen de bedrijfseconomie wordt deze als 'externe organisatie' omschreven.

${ }^{5}$ Zie Duderstadt, J.J. (2000). A University for the $21^{\text {st }}$ Century. Ann Arbor, Michigan: University of Michigan Press.

- Zie Electronic Fact Pages, http://www.umich.edu/ oapainfo/contents.html

${ }^{7}$ Zie Jaarverslag 1999, http://www.unimaas.nl/ \& Elsevier, Special October 2000

${ }^{B}$ Volgens studenten staat het Internationale Bedrijfskunde programma op plaats 1 , hoogleraren plaatsen het op nummer 3 .
} 
andere ziekenhuizen. Deze universiteit is een zogenaamde Research I Universiteit. Dat betekent volgens de Carnegie Classification (Carnegie Foundation for the Advancement of Teaching, 1994) dat zij geclassificeerd is als éen van de 88 Research I universities binnen de sector van meer dan 3500 instituten voor hoger onderwijs. ${ }^{\circ}$ Deze universiteit wordt geconfronteerd met krimpende overheidsbijdragen (als percentage van het totale budget), stijgende studentaantallen, toenemende concurrentie, en toenemende druk om zowel op onderzoek, onderwijs en services (o.a. Health Care) Value for Money te leveren. $\mathrm{De}$ Universiteit Maastricht is eveneens een onderzoeksuniversiteit. De verschillen in schaalgrootte zijn ongeveer 3:1 als het gaat om studentaantallen en wetenschappelijk medewerkers.

\section{Schaalomvang}

De eerste factor die een groot belang speelt in dit ecosysteem betreft de schaalomvang van het onderwijs. Volgens Francis en Hampton (1999) hebben de publieke research $1+\|$ universiteiten in de VS de afgelopen vijftig jaren zich zeer sterk aangepast aan sociale en economische veranderingen. In de eerste plaats werden het instituten die zich steeds meer richten op de groeiende middenklasse in plaats van de elite. In de tweede plaats gingen zij als kennisinstituut fungeren voor de industrie, gezondheidszorg en onderzoeksinstellingen. En in de derde, en laatste plaats, was er actieve bemoeienis om meer studenten uit bevolkingsgroepen te werven die voorheen niet deelnamen aan hoger onderwijs.

Deze ontwikkelingen zijn zichtbaar in verschillende data over veranderingen in de studentenmarkt. De deelname aan hoger onderwijs is in de VS de afgelopen dertig jaren sterk gestegen. Studeerden in 1960 nog 3 miljoen studenten, vijfendertig jaar later waren dat 15 miljoen studenten (Duderstadt, 2000). Voor het jaar 2010 schat men dat

\footnotetext{
${ }^{9}$ Research I universiteiten worden gekenmerkt door het aanbod van een full-range of baccalaureate programma's, verzorgen graduate programma's in meerdere disciplines, leveren meer dan 50 doctoraten per jaar, en geven hoge prioriteit aan onderzoek. Bovendien ontvangen zij van de Federale Overheid, op basis van onderzoeksprestaties, meer dan $\$ 40$ miljoen dollar per jaar aan onderzoeksmiddelen. Naast Research I universiteiten bestaan ook nog 36 Research II universiteiten die een federale onderzoeksbijdrage ontvangen tussen $\$ 15$ en $\$ 20$ miljoen. Research I + II universiteiten leveren in de VS een substantiële bijdrage aan de ontwikkeling van de kennisinfrastructuur door hun type afgestudeerden. Hoewel zij slechts $3 \%$ van het totaal aantal instellingen voor hoger onderwijs representeren, leveren zij $75 \%$ van alle Ph.D's, $35 \%$ van alle baccalaureaten en $56 \%$ van bachelors of Science.
} 
de groei doorzet tot ongeveer 20 miljoen full-time studenten (Dolence \& Norris, 1995). Meer dan $50 \%$ van de high school graduates zullen de komende jaren participeren in een of andere vorm van hoger onderwijs (Boyer Commission on Educating Undergraduates, 1998).

Maar het is niet alleen een kwestie van aantallen. De traditionele studentenmarkt (18 tot 22 jarigen) is namelijk de afgelopen jaren sterk veranderd in de Verenigde Staten. $\mathrm{Er}$ heeft een significante verschuiving in de gemiddelde leeftijd van studenten plaatsgevonden. Twintig jaar geleden bestond $80 \%$ van de studenten (full- en parttime) uit deze groep. De helft van de studenten zal de komende jaren daarentegen ouder zijn dan vijfentwintig jaar (Lewis \& Smith, 1994; Meister, 1998). Dat wordt niet veroorzaakt doordat de eeuwige student steeds langer aan de universiteit verblijft, maar doordat steeds meer volwassenen deelnemen aan universitair onderwijs. In het rapport "Life after Forty" (TERI-TIHEP, 1996) wordt gemeld dat tussen 1970 en 1993 het percentage studenten ouder dan veertig in alle sectoren van het hoger onderwijs is gegroeid met $235 \%$. Het aantal studenten nam toe in absoluut aantal van 477.000 tot 1.6 miljoen. In 1970 maakte deze groep nog 5.5\% van de totale instroom uit. In 1993 was het aandeel veertig+ studenten gestegen tot $11.2 \%$ van de totale studentenpopulatie. Het blijkt dat de veertig + groep met name participeert in de graduate programma's.

De belangrijkste redenen voor de veertig + groep om aan een universitaire studie te beginnen zijn veranderende eisen op de werkplek, veranderingen in levensomstandigheden en de persoonlijke behoefte aan scholing (ACT, 1993). Bovendien blijkt dat de veertig+ groep een grotere behoefte aan scholing heeft dan jongere werknemers. Veroudering van kennis en vaardigheden wordt als belangrijkste argument aangevoerd om aan scholing deel te nemen. Tenslotte, maar dat zal de ouderen in het publiek niet verbazen, blijkt dat deze groep betere studieresultaten behaalde dan de traditionele studentengroep, terwijl het studietempo significant lager lag in vergelijking bij de traditionele studenteninstroom.

Uit bovenstaande kan de conclusie getrokken worden dat publieke universiteiten in de VS niet meer als elite-instellingen fungeren. Ze zijn in een maatschappelijke situatie beland waarin toegang tot het hoger onderwijs als cruciaal ervaren wordt. Dat heeft niet alleen geresulteerd in een zeer sterke groei van de traditionele studentendoelgroepen, maar het heeft ook geleid tot het ontstaan van nieuwe doelgroepen. 


\section{Werkplek en arbeidsmarkt}

De industriële samenleving van de twintigste eeuw ontwikkelt zich tot een maatschappij waarin informatisering en digitalisering sleutelbegrippen vormen. De dominante technologie verschuift van machines naar computers, waar dien ten gevolge de output eveneens verandert: van goederen naar informatie. Vanwege de centrale rol die informatie- en communicatietechnologie in de samenleving heeft gekregen, wordt in dit verband ook wel gesproken van het tijdperk van "the Information Age" of "the Information Revolution" (Hamel \& Prahalad, 1994). Onderzoek toont aan dat innovatie in veel sectoren een steeds belangrijker wapen wordt in de internationale concurrentiestrijd (SER, 1995). Binnen deze context speelt specifieke kennis die niet bij andere ondernemingen bekend is een belangrijke rol teneinde een concurrentie voorsprong te behouden. Het belang van kennis en de rol van kenniswerkers wordt geillustreerd aan de hand van enkele cijfers die betrekking hebben op de arbeidsmarkt in de VS. Het aandeel productiewerkers (agrarische sector, industrie) is de afgelopen honderd jaar gehalveerd tot ongeveer $40 \%$ van de totale populatie, terwijl in dezelfde periode het aandeel kenniswerkers (arbeidskrachten die informatie omzetten in kennis met behulp van eigen competenties, of met hulp van specialistische kennisleveranciers zoals in de commerciële dienstensector, technologie, professionele dienstensector) steeg van $17 \%$ tot ongeveer $60 \%$ (Business-Higher Education Forum, 1996, 1999; Meister, 1998; Sveiby, 1998).

Vergelijkbare veranderingen in de aard van de werkplek, en veranderingen op de arbeidsmarkt worden trouwens ook gerapporteerd door onderzoekers van het ROA als we naar de Nederlandse en WestEuropese situatie kijken (Borghans, Delmee, Marey, \& Vlasblom, 1998). Het ROA komt tot de conclusie dat er een tendens tot upgrading zichtbaar is. Hetgeen erop neer komt dat werkgevers vanwege de toegenomen complexiteit van het werk, steeds vaker om academici vragen. Dat betekent ook dat naarmate werknemers in hogere functies terecht komen er een toenemend belang wordt toegeschreven aan vaardigheden zoals communicatieve vaardigheden, algemene vaardigheden (zoals het vermogen het werk te ordenen en te organiseren), en managementvaardigheden. De onderzoekers komen ook tot de conclusie dat met omscholing van werkenden slechts een kleine bijdrage aan het verkleinen van de knelpunten op de arbeidsmarkt kan worden geleverd. En wellicht de meest in het oog springende conclusie is, en ik citeer letterlijk: "Er zijn in alle scenario's te weinig hoog opgeleiden beschikbaar om aan de verwachte (zeer) hoge vraag te voldoen." (Borghans, Delmee, Marey, \& Vlasblom, 1998; p.85) 
Daarmee zijn we terug bij de situatie op de arbeidsmarkt in de VS. Kijken we naar het kwantitatieve kant van deze problematiek dan valt op dat er steeds vaker een pleidooi wordt gehouden om universiteiten als instrument in te zetten tegen het tekort aan hoger opgeleiden, bijvoorbeeld door universitaire bijscholing van veertigplussers (TERI, 1996). Aan de kwalitatieve kant, wordt door werkgevers geconstateerd dat afgestudeerden gebrek hebben aan een aantal vaardigheden: leiderschap, teamwork, problem-solving, time management, selfmanagement, adaptability, analytical thinking, global considerations, basic communications (Bowden \& Marton, 1998; Business-Higher Education Forum, 1999). Onderzoek van Harvey en Green (1993) toont aan dat merkwaardiger wijze het bezitten van specialistische kennis bij werkgevers nooit hoog scoort in vergelijking met de eerder genoemde vaardigheden. De hypothese dat werkgevers die kennis als vanzelfsprekend aanwezig achten en dus naar toegevoegde waarde (in de vorm van de genoemde vaardigheden) zoeken werd niet in diens onderzoek bevestigd. Het tegendeel bleek het geval te zijn. Werkgevers gaan uit van een korte levenscyclus van kennis, en zoeken meer naar afgestudeerden die over de vaardigheid beschikken om zich nieuwe kennis eigen te maken en die toe te passen.

Daarmee zijn we bij de tweede factor aanbeland. Uit bovenstaande blijkt dat werkgevers vooral belang hechten aan generieke vaardigheden gezien de korte levenscyclus van kennis. In die optiek maken nieuwe werknemers zich de bedrijfsspecifieke kennis eigen na afloop van de studie, maar niet tijdens de studie. Universiteiten proberen door middel van hun vormingsideaal aan dezelfde eis tegemoet te komen, maar blijken in de praktijk dat niet of nauwelijks te kunnen realiseren. Zo blijkt bijvoorbeeld uit een reeks van studies dat de ontwikkeling van dergelijke generieke vaardigheden slechts kan plaatsvinden door deze te koppelen aan inhouden (Bowden \& Marton, 1998; Bransford \& Schwartz, 1999). Bransford en Schwartz waarschuwen zelfs dat "A potential danger of the preparation for future learning perspective is that it could lead to claims such as "I'm teaching for future learning, so I don't worry about mastery of content."

\section{Kennisproductie en Kennisdistributie}

Dat brengt me tot de derde, en laatste, factor die effect heeft op het functioneren van het eco-systeem waarbinnen universiteiten opereren. Een van de meest in het oog springende fenomenen betreft de opkomst van zogenaamde corporate universities. Bruining (2000) onderscheidt drie generaties van dit fenomeen. Corporate universities zijn niet 
vergelijkbaar met de bestaande universiteiten, hoewel hun naam dat enigszins suggereert. Ze passen veel eerder in het concept van levenslang leren. Bedrijven richten deze instellingen op om kennisproductie en kennisdistributie te bevorderen die bedrijfsspecifiek is. De metafoor van een universiteit schuilt in het idee dat corporate universities ook een bijdrage leveren aan kennisproductie.

Een tweede type aanbieder betreft de zogenaamde commerciële aanbieders van universitair onderwijs. Daarmee bedoel ik instellingen met winstoogmerk die voor iedereen toegankelijk zijn, en de mogelijkheid bieden tot het verkrijgen van universitaire diploma's. De belangrijkste ontwikkeling die zich op dit terrein voordoet is dat sommige universiteiten gekozen hebben voor het aanbieden van postgraduate onderwijs via een externe, commerciële 'provider'. De universiteiten zijn verantwoordelijk voor het vullen van cursussen met academische inhoud, de provider doet de rest (marketing, logistiek, ontwikkelen en onderhoud van de onderwijstechnologie).

Twee van dergelijke providers zijn noemenswaard. In de eerste plaats Unext.com. Dit bedrijf heeft een nieuwe Internet universiteit opgericht (de zogenaamde Cardean University) waarin voor honderd miljoen dollar geïnvesteerd is. Krijgen van marktaandeel in de lucratieve MBAmarkt staat voorlopig voorop. De doelgroep bestaat uit mensen die geen tijd hebben om regelmatig (bijvoorbeeld iedere Vrijdag) naar een universiteit te reizen, en degenen die reeds over een universitair diploma beschikken maar waarbij verdere scholing noodzakelijk is voor de verdere carrière. Voor de inhoud wordt gezorgd door toonaangevende Business Schools. ${ }^{10}$

De tweede belangrijke aanbieder is FT-Knowledge." Dit bedrijf produceert bedrijfsopleidingen en werkt op de MBA-markt in de VS samen met de University of Michigan en Wharton Business School van de University of Pennsylvania (Blumenstyk, 2000). ${ }^{12}$ FT hanteert een iets andere strategie dan Unext door programma's aan te bieden die een mix bevatten van contact-onderwijs en afstandsonderwijs.

Bovenstaande ontwikkelingen vinden thans plaats binnen de VS. Meestal geeft dat de zekerheid dat het nog minstens tien jaar duurt voordat de gevolgen van dit soort ontwikkelingen in West-Europa merkbaar zijn. Het is daarom des te meer opmerkelijk dat recent de

\footnotetext{
${ }^{10}$ Alle genoemde Business Schools maken deel uit van de Top Twintig van Best Bschools volgens Business Week / October 2, 2000 en FT.Com

$"$ Een divisie van het in London gevestigde Pearson P.L.C. die onder andere de Financial Times uitgeeft

${ }^{12}$ Beide universiteiten bieden MBA-programma's die in de Top Twintig van Best Bschools staan Business Week / October 2, 2000 en FT.Com.
} 
Business School van Cambridge University een contract met FT heeft getekend voor het verzorgen van MBA-programma's waarin afstandsonderwijs afgewisseld wordt met face-to-face teaching. FT levert de kennis voor de technische productie, de electronische levering, logistiek en marketing.

Ik zou bij deze ontwikkeling een aantal kanttekeningen willen maken. In de eerste plaats is het maar de vraag in hoeverre kennisproductie en kennisdistributie tot het primaire bedrijfsproces gerekend mogen worden (Davis \& Botkin, 1994). Immers, hoe meer kennis een organisatie produceert, hoe moeilijker het wordt om die kennis binnen de organisatie te behouden. In de tweede plaats doet zich de vraag voor of bestaande universiteiten door hun uitverkoop van kennis aan commerciële aanbieders, in staat zijn om de opbrengsten te vertalen in investeringen voor de ontwikkeling van duurzame kennis. In de derde, en laatste, plaats blijkt dat commerciële aanbieders zich vooral bewegen op financieel aantrekkelijke markten: professies waarin levenslang leren steeds belangrijker wordt zoals business. Dat laatste plaatst publieke universiteiten in de positie dat zij lucratieve studentenmarkten dreigen kwijt te raken, terwijl zij tegelijkertijd wel voor de kosten mogen opdraaien om minder aantrekkelijke studies (wat betreft studentaantallen) te blijven aanbieden.

Bewijst dit het gelijk van Cliteur (2000) en Klamer (2000) als zij stellen dat universiteiten zich minder door de tucht van de markt moeten laten beïnvloeden? Bruining (2000) wijst erop dat in deze discussie appels met peren vergeleken worden. In zijn optiek houden universiteiten zich bezig met de productie van abstracte theorieën en concepten die lange termijn geldigheid beogen. Gibbons (1997) noemt omschrijft dit soort kennis als Modus I. Haaks daarop staat de productie van kennis die binnen een bepaald toepassingsgebied is ontwikkeld, die multidisciplinair is, en die een beperkte geldigheid heeft: de zogenaamde Modus II kennis. En daarmee is de derde factor gedefinieerd: Modus I versus Modus II. 


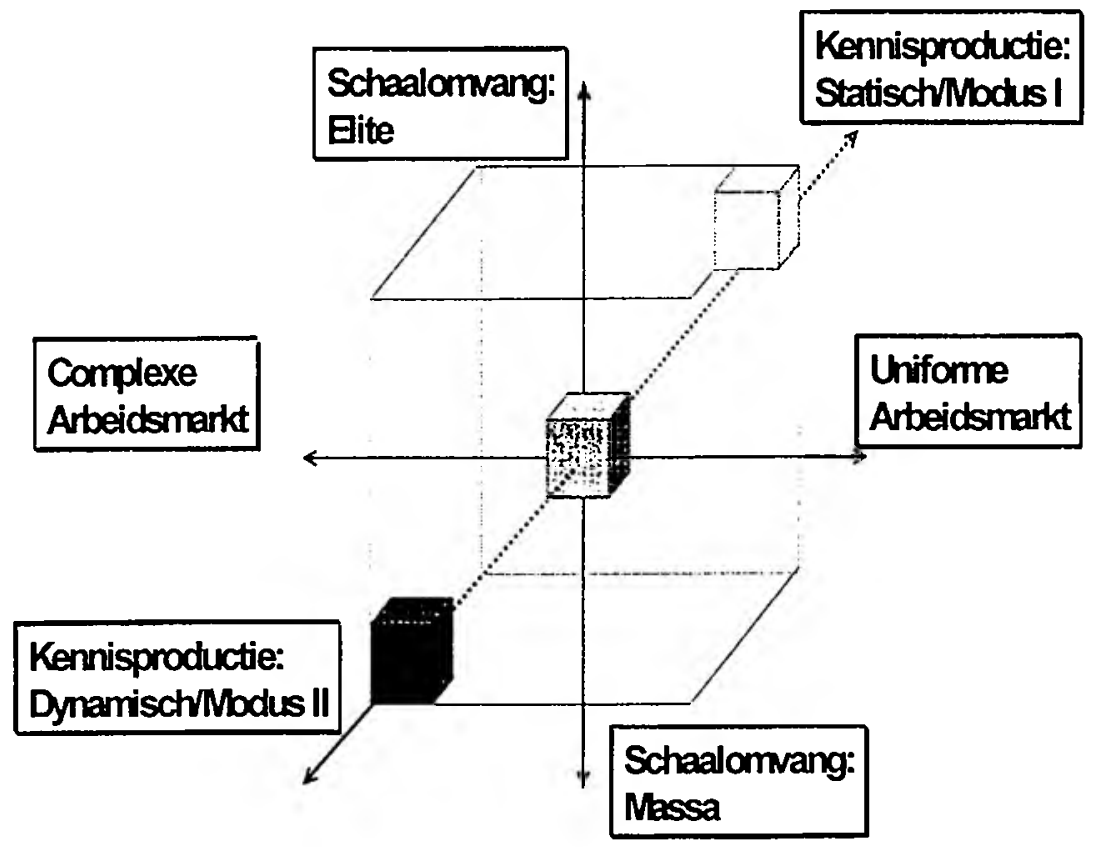

Figuur 2: Factoren van invioed op strategische besluitvorming

Figuur 2 geeft de eerder beschreven factoren weer die een rol spelen bij de strategische besluitvorming van universiteiten in de Verenigde Staten (Duderstadt, 2000). Uit deze figuur blijkt bijvoorbeeld dat aanhangers van de opvatting dat de universiteit weer een academie moet zijn, zoals bijvoorbeeld Klamer en Cliteur, rechtsboven in de kubus geplaatst kunnen worden. Immers beide auteurs wijzen invloed van de markt af, en stellen een onderwijsmodel voor dat feitelijk alleen hanteerbaar is bij relatief kleine aantallen studenten. Discutabel in bovenstaande figuur is of zij wel of niet uitgaan van een complexe arbeidsmarkt (dynamische ontwikkeling in nieuwe en bestaande functies) of een uniforme arbeidsmarkt (statisch, met duidelijk omschreven functies). Corporate universities kunnen in de kubus linksonder geplaatst worden. Deze zijn namelijk gericht op grote aantallen studenten, de kennisdistributie is bedrijfsspecifiek en heeft een korte levenscyclus, en men opereert in een complexe arbeidsmarkt. 
Auteurs als Duderstadt (2000) en Rowley et al (1998) benadrukken dat de bestaande onderzoeksuniversiteiten duidelijke keuzes moeten maken. Men kan niet en op grote studenten aantallen gericht zijn, en op academische vorming, en op een complexe arbeidsmarkt. Bovendien benadrukken beide auteurs een inrichting van het universitair onderwijsmodel waarbij studenten competenties verwerven zoals die eerder gedefinieerd werden bij de Nieuwe geleerden. De daavoor noodzakelijke onderwijsaanpak lijkt als twee druppels water op het klassieke Maastrichtse PGO. Wat men toevoegt aan het Maastrichtse model is dat men pleit voor de oprichting van zogenaamde kennisnetwerken waarin afgestudeerden levenslang toegang krijgen tot de beschikbare kennis binnen de universiteit, dat de samenwerking tussen disciplines en werkveld gestalte krijgt door curricula aan te passen, dat men zich meer gaat opstellen als certificaatverlener van leerwegen (bijvoorbeeld als studenten in het buitenland ervaring opdoen), dat curricula op ieder moment toegankelijk moeten zijn voor verschillende studenten (afhankelijk van hun voorkennis), en dat technologie geïntegreerd wordt in het onderwijs.

Uiteraard kan men van dergelijke adviezen beweren dat ze te vaag, niet uitvoerbaar, of zelfs niet academisch zijn. Maar ik wil twee adviezen nader onder de loep nemen: 1) universiteiten moeten de toegang tot kennis verbeteren voor afgestudeerden, en 2) universiteiten moeten investeren in de ontwikkeling van nieuwe leeromgevingen.

\section{Transitie Leren - Werken}

De afgelopen jaren heb ik met een aantal collega's een reeks onderzoeken gedaan naar kennisontwikkeling in het domein van de Managementwetenschappen (Arts, Boshuizen \& Gijselaers, 2000; Gijselaers \& Arts, 2000; Arts in voorbereiding). In deze onderzoeken is gekeken naar de wijze waarop studenten kennis verwerven binnen het vakgebied Organisatie. Alle proefpersonen kregen twee casus voorgelegd die representatief werd geacht voor het organisatieadvieswerk. Proefpersonen verschilden in de mate waarin men expertise had opgedaan binnen het domein van de Organisatiewetenschappen. Het verschil kon uiteenlopen van maximaal twee weken verblijf op de Faculteit der Economische Wetenschappen en Bedrijfskunde tot 25 jaar post-doc ervaring. Proefpersonen werd naast een aantal metingen die we hier buiten beschouwing laten gevraagd om zich in de rol van organisatie-adviseur te plaatsen en oplossingen aan te dragen voor de in de casus beschreven 
problematiek. In de analyse van de resultaten werden de aangedragen oplossingen gescoord als correct, partieel correct, en incorrect. Figuur 3 bevat de resultaten van dit onderzoek.

Uit figuur 3 blijkt dat tijdens de studie (Expertise niveau: $0 \mathrm{t} / \mathrm{m} 4$ jaar) studenten meer partieel correcte oplossingen produceren bij een casus dan correcte oplossingen. Ook blijkt de groei van het aantal partieel correcte oplossingen groter dan het aantal correcte oplossingen. $\mathrm{Na}$ het afstuderen slaat het beeld om, en treedt een daling in het aantal partieel correcte oplossingen, terwijl het aantal correcte oplossingen blijft toenemen. Pas zes jaren na het afstuderen wordt een fase bereikt waarin het aantal correcte oplossingen groter is dan het aantal partieel correcte oplossingen.

Expertise-ontwikkeling $M$ W

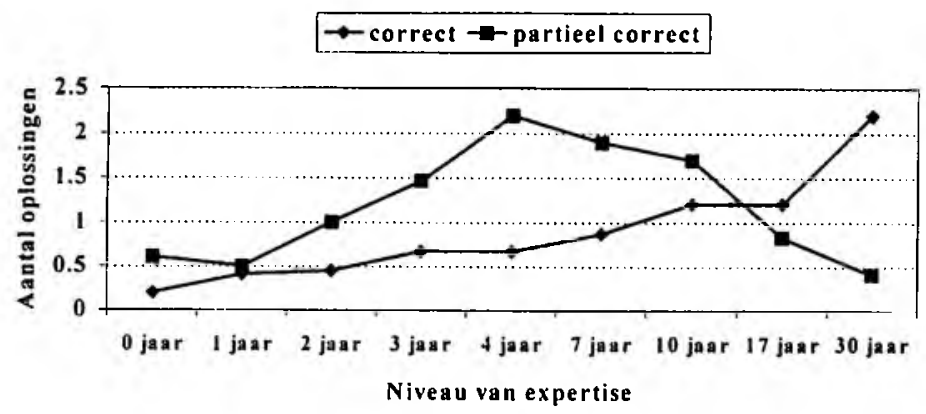

Figuur 3: Correcte en Partieel Correcte oplossingen (Arts, in voorbereiding)

Suggereren deze resultaten dat voorstanders van de Nieuwe geleerden gelijk hebben? Dat wil zeggen dat studenten na het afstuderen over onvoldoende probleemoplossende vaardigheden beschikken? Voor een deel wel. Hoewel aangetekend moet worden dat a) tijdens de studie blijkbaar flink geleerd wordt, ook al is dat voor een groot deel partiële kennis, en b) dat in de overgang naar de werkplek de eerste jaren een combinatie van afleren en doorleren optreedt. Naar het schijnt worden trouwens vergelijkbare resultaten gevonden in de overgang van preklinisch onderwijs naar kliniek, maar dat terzijde. Het belang van dit onderzoek schuilt in mijn optiek in het feit dat universiteiten veel meer hun potentieel zouden kunnen benutten bij het begeleiden van afgestudeerden. Onderwijs zou veel krachtiger effect kunnen hebben 
als afgestudeerden toegang kregen tot de binnen universiteit aanwezige expertise door praktijkkennis te koppelen aan de zogenaamde Modus I kennis. Wat dat betreft ondersteun ik het pleidooi van auteurs als Duderstadt (2000) dat universiteiten een omslag in hun denken moeten maken, zodat het onderwijs (of toegang tot onderwijs) niet bij de diploma-uitreiking ophoudt.

\section{Van PGO naar ePGO?}

De afgelopen twee jaren hebben medewerkers van mijn departement intensief samengewerkt met de sectie Marketing van het departement Managementwetenschappen, aan de ontwikkeling van een radicale variant op het Maastrichtse PGO. ${ }^{13}$ Binnen het studeerbaarheidsproject "de Werkelijkheid Gevangen" werden authentieke cases ontwikkeld en verzameld voor het onderwijs binnen het Marketing vakgebied. Er werd een onderwijsmodel ontwikkeld waarin de problematiek werd aangeleverd door een bekend bedrijf uit de cosmetica-industrie. Er was slechts plaats voor één onderwijsgroepbijeenkomst per week. Studenten werkten tussentijds in kleine teams, communicatie vond electronisch plaats via WebBoard, en de groepsbijeenkomsten waren niet op kennisreproductie gericht, maar op het produceren van nieuwe kennis zoals ingebracht door de afzonderlijke teams.

\footnotetext{
${ }^{13}$ Het projectteam bestond uit Jos Arts, Wim Gijselaers en Mien Segers (Departement Onderwijsontwikkelingen en Onderwijsresearch, UM) en Mirella Kleijnen, Jos Lemmink, en Anoek Lievens (Departement Managementwetenschappen, sectie Marketing).
} 


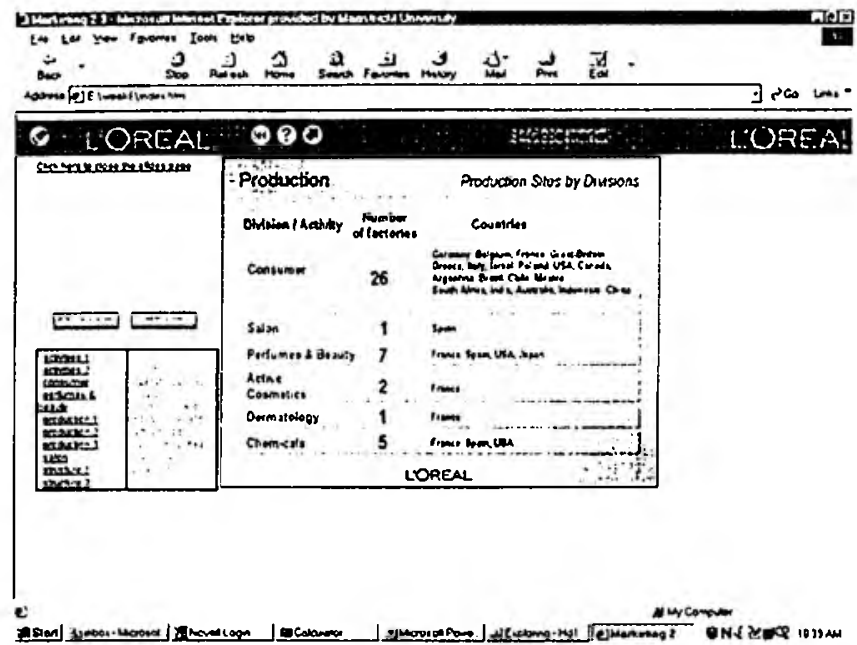

Figuur 4: Voorbeeld van een scherm uit de multimedia-case

Uit onze evaluaties blijkt dat studenten die aan het experiment hebben deelgenomen het volgende commentaar geven:

- Het onderwijsmateriaal wordt als zeer stimulerend ervaren;

- De authentieke leeromgeving (onderwijsmateriaal plus werkwijze) wordt als zeer positief beoordeeld. Studenten zijn vooral positief over de combinatie van flexibel studeren aan de ene kant, in combinatie met het bieden van een duidelijke structuur aan de andere kant;

- Het ontwikkelen van een goede authentieke leeromgeving vereist een goede training van docenten en studenten vooraf, is zeer arbeidsintensief voor docenten wat betreft ontwikkeling en uitvoering, en vereist een intensieve samenwerking tussen onderwijskundige en vakdocenten.

Om effecten van deze leeromgeving op de leerresultaten te meten werd een onderzoeksopzet ontworpen waarin drie verschillende tutoren ieder met drie verschillende groepen uit het betreffende blok werkten. ledere tutor kreeg één experimentele groep (de zogenaamde e-learning groep) ${ }^{14}$ onder begeleiding, één groep volgens het traditionele PGO (de PGO-groep, bestaande uit studenten zonder PC met

\footnotetext{
${ }^{14}$ De e-learning groepen bestond uit random ingedeelde groepen. Studenten waren uit een populatie geselecteerd die thuis beschikten over een PC met Internet aansluiting.
} 
Internetaansluiting), en éen groep (de PGO-select groep) waarin volgens het traditionele PGO werd gewerkt maar met studenten die thuis wel Internet aansluiting hadden. Alle groepen bestonden uit veertien studenten. Alle groepen kregen dezelfde bloktoets, dezelfde markt-onderzoekopdracht, en dezelfde literatuur. De traditionele PGOgroep en de PGO-select groep kregen hetzelfde onderwijsmateriaal, en verschilden uitsluitend of studenten thuis over een PC met internetaansluiting beschikten. Studenten mochten niet van groep wisselen. De drie tutoren waren intensief betrokken bij de opzet van het e-learning onderwijsmateriaal, en vormgeving van de instructie. Toetsen werden in alle condities op gelijke wijze door onafhankelijke beoordelaars gescoord. Alle toetsen speelden een summatieve rol. Naast de traditionele toetsen werden aan het einde van het blok authentieke cases in alle groepen afgenomen met als doel een meting te verrichten naar de ontwikkeling van probleemoplossende vaardigheden. ${ }^{15}$

De resultaten uit het onderzoek naar effecten van de nieuwe leeromgeving staan afgebeeld in figuur 5 .

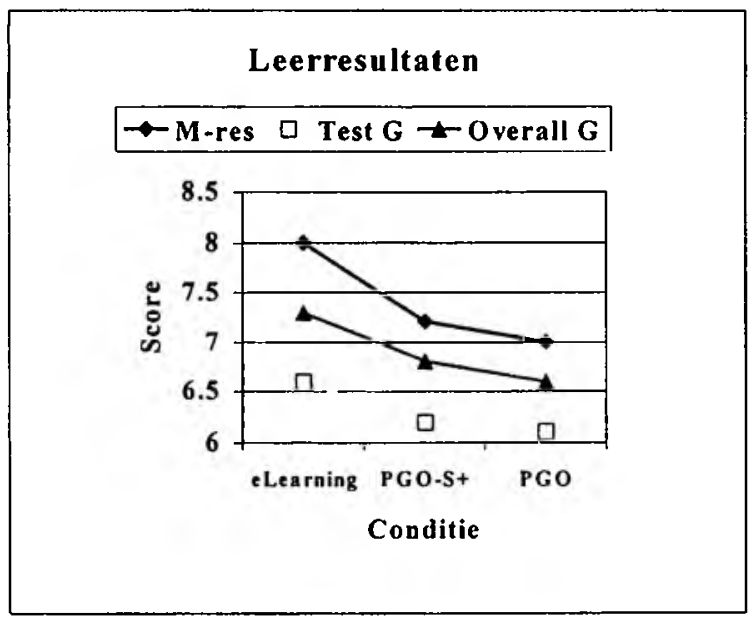

Figuur 5: Toetsresultaten onderzoek "De werkelijkheid gevangen"

${ }^{15}$ De resultaten van deze meting waren bij het publiceren van deze oratie nog niet beschikbaar. 
Figuur 5 bevat de scores op drie toetselementen: 1) resultaten op het rapport dat studenten in het kader van een marktonderzoek moesten schrijven (M-Res), 2) de score op de bloktoets (bestaande uit open en multiple-choice vragen), en 3 ) het eindcijfer voor het blok (bestaande uit participatiebeoordeling 20\%; resultaat marktonderzoek $40 \%$; en bloktoetsresultaat 40\%). Uit de resultaten blijkt dat er statistisch significante verschillen ten aanzien van de leerresultaten bestaan tussen de e-learning conditie en de PGO-conditie. Met name de effecten op de marktonderzoekresultaten zijn aanzienlijk. Ook blijkt bij nadere analyse dat effecten op de bloktoets alleen bestaan bij de antwoorden op open vragen, en niet bij de multiple-choice vragen. De resultaten uit dit onderzoek geven een voorzichtige indicatie dat studenten in de e-learning conditie niet alleen positiever waardeerden, maar ook dat de resultaten op metingen die meer dan alleen feitenkennis meten aanzienlijk hoger liggen.

Het hier geschetste onderzoek is in mijn optiek een toonbeeld van vruchtbare samenwerking tussen de experts binnen een vakgebied en collega's van mijn departement. Het onderzoek laat zien hoe ICT op een zodanige wijze geïntegreerd kan worden in nieuwe vormen van PGO die aantoonbaar positieve effecten op het leren. Tevens wordt zichtbaar hoe nieuwe 'slimme' versies van PGO ontwikkeld kunnen worden door ingrijpende veranderingen in te brengen in de aloude systematiek van het PGO-rooster, het gebruik van taken, en de manier waarop met de industrie samengewerkt kan worden om modern en authentiek onderwijsmateriaal te ontwikkelen. Tenslotte is het mijn ogen evident dat hier getoond wordt dat zorgvuldigheid bij de planning en implementatie van onderwijs uiteindelijk beloond wordt door betere onderwijsleerresultaten. De resultaten van dit project vragen dan ook logischer wijze om een vervolg.

\section{Onderwijsontwikkeling en de rol van Onderwijsonderzoek}

De komende jaren wil ik de eerder geschetste onderzoekslijnen van kennis-ontwikkeling binnen het (bedrijfs)economisch domein en de ontwikkeling van nieuwe varianten van PGO verder uitbouwen. Het zal duidelijk zijn dat ik een fervent voorstander ben van bijstelling van het traditionele Maastrichtse PGO-model, teneinde het onderwijs beter te laten aansluiten op de arbeidsmarkt. Uit mijn betoog blijkt ook dat ik ervan overtuigd ben dat de komende jaren meer onderwijskundige veranderingen op de FdEWB en UM afkomen dan ons lief is. Tegelijkertijd is dat ook een uitdaging. 
De FdEWB heeft afgelopen jaar al maatregelen genomen om zich op de komende veranderingen voor te bereiden. Met het goedkeuren, en reserveren van de benodigde financiële middelen, van het zogenaamde "Koersen op Kwaliteit" plan wordt blijk gegeven van de noodzaak tot systematische onderwijsontwikkeling. Op een aantal punten, zoals het verbeteren van onderwijsinformatiesystemen, de integratie van ICT in het onderwijs, en docentprofessionalisering loopt de FdEWB zelfs voorop in het initiëren van vergaande onderwijsontwikkeling. Tegelijkertijd moet geconstateerd worden dat faculteitsbrede implementatie van dergelijke initiatieven vaak moeizaam verloopt door de hoge druk op het leveren van onderzoekprestaties, en de aanhoudend hoge studenten-instroom.

De veranderende opvattingen over de rol van universiteiten als kennisproducent en kennisdistributeur worden ook de komende jaren zichtbaar in het onderzoek binnen mijn departement. Recent is door de MaGW van NWO een onderzoeksproject, in samenwerking met Prof. $P$. Kirschner van het OTEC (OU-NL), goedgekeurd waarin bekeken wordt hoe professionals in teams kennis produceren en uitwisselen, en de wijze waarop ICT daarin een faciliterende rol kan spelen. Dergelijk onderzoek heeft zowel duidelijke relaties met onderzoek dat binnen Meteor en Infonomics plaatsvindt naar de rol van kennis in de nieuwe economie, als naar het ICO wat betreft de effecten van samenwerkend leren. In dat verband is het uiterst merkwaardig dat de PROO van NWO geen projectaanvragen over onderwijskundig onderzoek in het hoger onderwijs in behandeling neemt. Ik bepleit dan ook een koerswijziging van de PROO wat betreft de prioriteitenstelling van onderwijskundig onderzoek. Het kan in mijn optiek niet zo zijn dat het onderwijskundig onderzoek de aansluiting verliest met onderzoek dat thans plaatsvindt op terreinen van kenniseconomie, scholing en arbeidsmarkt.

Tot besluit wil ik het belang van de nieuwe opleiding Onderwijswetenschappen binnen de UM benadrukken. De UM heeft de afgelopen vijfentwintig jaar een uniek en niet kopieerbaar kennisarsenaal opgebouwd wat betreft de ontwikkeling, implementatie, en evaluatie van radicale onderwijsvernieuwing. Haar reputatie op dit terrein is buitenshuis groter dan binnenshuis vaak gedacht wordt. Ik hoop dat dit een goede basis vormt voor de verdere ontwikkeling van deze opleiding en de daarmee gepaard gaande onderzoeks- en adviesactiviteiten. 


\section{Dankwoord}

Geachte Rector, Dames en Heren,

Eigenlijk ben ik al veel langer aan het woord geweest dan vanuit onderwijskundig perspectief nog verantwoord is. Toch wil ik graag enkele woorden van dank uitspreken. Op de eerste plaats wil ik het College van Bestuur van de Universiteit Maastricht, en het bestuur van de Faculteit der Economische Wetenschappen en Bedrijfskunde bedanken voor mijn benoeming. Ik hoop dat ik de komende jaren een bijdrage kan leveren aan verdere intensivering van onderwijsvernieuwing en de ontwikkeling van onderwijsonderzoek.

Ik heb negentien jaar geleden de gelukkige keuze gemaakt om als jonge Nijmeegse onderwijskunde student naar het toen nog onbekende Maastricht af te reizen alwaar ik een stageplaats bij de zogenaamde RUL kreeg. De capaciteitsgroep Onderwijsontwikkeling en Onderwijsresearch was pas kort tevoren opgericht, en bestond uit een betrekkelijk kleine groep medewerkers. Mijn plan was om er één jaar te blijven, en daarna als methodoloog verder te trekken naar een of ander onderzoeksinstituut. Maar plannen zijn vaak achteraf constructies. Vanaf de eerste dag ondervond ik hoeveel meer weerbarstig de onderwijskundige praktijk kan zijn in vergelijking met wat in de handboeken staat. En dat maakt het juist zo interessant. Vanaf de eerste dag werd ik in een groep opgenomen die met grote toewijding het zogenaamde Maastrichtse PGO ontwikkelde, en waarin teamwerk als vanzelfsprekendheid werd beschouwd. Ik wil dan ook alle collega's bedanken voor hun begeleiding, inbreng, ideeën, en persoonlijke belangstelling. Een persoonlijk dankwoord gaat uit naar Els Boshuizen en Cees van der Vleuten voor hun stimulerende inbreng bij het ontwikkelen van nieuwe onderwijs- en onderzoeksprogramma's.

Mijn promotoren Henk Schmidt en Wynand Wijnen van de Universiteit Maastricht wil ik persoonlijk bedanken voor het feit dat ze me leerden hoe belangrijk het is om passie en creativiteit voor onderwijskundig onderzoek te ontwikkelen.

Mijn collega's van het departement O\&O-FdEWB, Jos Arts, Geke Blok, Piet van den Bossche, Tamerius Cohen, Henny Dankers, Jeannette Hommes, Els Huijgens, Paul Jacobs, Ellen Nelissen, Mien Segers wil ik persoonlijk bedanken voor hun gedreven aanpak van het werk, en hun vermogen om daadwerkelijk als een goed team te kunnen functioneren. 
Graag wil ook alle collega's binnen de FdEWB bedanken met wie ik de afgelopen vijftien jaren heb samengewerkt. En dat is een nog langere namenlijst dan die van O\&O-FdEWB. Ik beperk me daarom tot het noemen van enkele collega's die vaak zonder dat ze het wisten een belangrijke stempel op mijn werk drukten. Bram Beek, Hans Kasper, Joan Muysken, en Frans Palm leerden mij hoe belangrijk het is dat onderwijskundigen ook kennis hebben van het management van onderwijsorganisaties. Rene Verspeek wil ik bedanken voor zijn zichtbare steun aan het EDINEB-netwerk, en het EDINEB stichtingsbestuur wil ik noemen voor hun onvermoeibare inzet voor het ontwikkelen van dat netwerk. Binnen EDINEB verband wil ik apart Ellen Nelissen bedanken zonder wie vele plannen reeds op de tekentafel zouden zijn gesneuveld.

Mijn ouders wil ik bedanken dat ze het vanzelfsprekend vonden dat ik ging studeren in een tijd waarin studeren nog niet vanzelfsprekend was. En zeker dat ze me een studie lieten volgen waarbij ik zelf grote moeite had om uit te leggen wat deze eigenlijk inhield. Ik hoop dat ik dat laatste vandaag alsnog heb kunnen doen.

Marjan, Maartje en Sybren met een dankwoord aan jullie sluit ik deze oratie af. Wie mij kent weet hoe belangrijk jullie voor mij zijn. Wat de meeste mensen niet weten is dat jullie dat in de regel liever stil houden. Ik wil deze keer toch van deze regel afwijken door te melden dat Maartje verantwoordelijk was voor de animaties in mijn oratie, Marjan zoals te doen gebruikelijk mij dagelijks gevraagd en ongevraagd advies gaf over de inhoud van de oratie, en Sybren mij verzocht om vooral de spreektijd in de gaten te houden en het publiek op de mogelijkheden van Internet te wijzen. Jullie begrijpen dat ik met genot een dergelijk team koester en dat ik uitkijk naar de volgende familieprojecten.

Daarmee ben ik aan het einde van mijn rede gekomen. Ik bedank $u$ allen voor uw aanwezigheid.

Ik heb gezegd. 


\section{Referenties}

Alexander, F.K. (2000a). The changing face of accountability. The Journal of Higher Education, 71, 411-431.

American College Testing (ACT) (1993). Adult Learner Needs Assessment Survey, IOWA City, ACT.

Arts, J.A., Boshuizen, H.P.A., \& Gijselaers, W.H. (2000, April). Expertise development in managerial sciences: the use of knowledge in problem-solving. Paper presented at the Annual Meeting of the American Educational Research Association, April 2000.

Arts, J.A. (in voorbereiding). Academisch proefschrift. Universiteit Maastricht.

Blumenstyk, G. (2000). Cambridge university will collaborate with a media giant on an online MBA. Corporate Universities International, September/October, 9. Reprinted with permission of The Chronicle of Higher Education, 8/4/00 issue.

Borghans, L., Delmee, J., Marey, P., \& Vlasblom, J.D. (1998). Toekomstverkenning arbeidsmarkt en scholing tot 2007. 'sGravenhage: Elsevier Bedrijfsinformatie.

Bowden, J., \& Marton, F. (1998). The university of learning. Beyond quality and competence in higher education. London: Kogan Page.

Boyer Commission Report (1998). Reinventing undergraduate education: A blueprint for America's research universities. Stony Brook: New York.

Bransford, J. D., \& Schwartz, D. L. (1999). Rethinking transfer: A simple proposal with multiple implications. Review of Research in Education, Volume 24, 61-100.

Bruining, A.W.M. (2000). Toegevoegde waarde van corporate universities. Opleiding en Ontwikkeling, 9, 7-9

Business-Higher Education Forum (1996). Higher education and work readiness: The view from the Campus. Washington, DC.

Business-Higher Education Forum (1999). Spanning the chasm: A blueprint for action. Washington DC.

Cliteur, P. (2000). Academicus moet net zo vrij zijn als de rechter. NRC, september 21, 6 .

Davis, S., \& Botkin, J. (1994). The monster under the bed. How business is mastering the opportunity of knowledge for profit. New York: Touchstone.

Dolence, M.G., \& Norris, D.M. (1995). Transforming higher education. Ann Arbor, Mich.: Society for College and University Planning. 
Duderstadt, J.J. (2000). A university for the $21^{\text {st }}$ century. Ann Arbor: The University of Michigan Press.

Electronic Fact Pages (2000). University of Michigan, Ann Arbor. http://www.umich.edu/ oapainfo/TABLES/Enr_Gen.html

Feltovitch, P.J., \& Barrows, H.S. (1995). A proposal to establish a center for education for the complex and changing workplace. Internal Report Department of Medical Education, Southern Illinois University School of Medicine, Springfield, Illinois.

Feldman, K. (1987). Research productivity and scholarly accomplishment of college teachers as related to their instructional effectiveness: A review and exploration. Research in Higher Education, 26, 227-298.

Francis, J.G., \& Hampton, M.C. (1999). Resourceful responses. The adaptive research university and the drive to the market. The Journal of Higher Education, 70, 625-641.

Gibbons, M. (1997). New production of knowledge: Dynamic of science and research in contemporary society. London: Sage Publications.

Gijselaers, W.H., \& Arts, J.A. (2000, April). Effects of gender and mood on recall in expertise research. Paper presented at the Annual Meeting of the American Educational Research Association, April 2000.

Hamel, G., \& Prahalad, C.K. (1994). Competing for the future. Boston, MA: Harvard Business School Press.

Harvey, L., \& Green, D. (1993). Defining quality. Assessment and Evaluation in Higher Education, 18, 9-34.

Hattie, J., \& Marsh, H.W. (1996). The relationship between research and teaching: A meta-analysis. Review of Educational Research, $66,507-542$.

Holleman, W., Berg, I. van den, Oost, H., Thoolen, B., \& Admiraal, W. (1998). Vijf definities van academische vorming. THEMA, 5, 4-9.

Humboldt, von, W. $(1809,1970)$. On the spirit and the organizational framework of intellectual institutions in Berlin. Minerva, 8, 242-267. Oorspronkelijk gepubliceerd in 1809.

Klamer, A. (2000). Universiteit moet academie durven zijn. NRC, september $4,7$.

Lenzer, R., \& Johnson, S.S. (1997). Seeing things as they really are. Peter Drucker Interview, Forbes, 159, 122-128.

Meister, J.C. (1998). Corporate universities. Lessons in building a worldclass work force. Revised and updated edition. New York: McGrawHill.

Mirande, M.J.A. (1995). Wenselijk geachte universitaire opleidingsdoelen. Tijdschrift voor Hoger Onderwijs, 13(1), 54-68. 
Nedermeijer, J.,\& Vos, P. (1999). Academische vaardigheden in de propedeuse van academische opleidingen. Tijdschrift voor Hoger Ondenwijs, 17(2), 101-121.

Newman, J.H. (1853). The idea of a university. Garden City, NY: Doubleday.

Noam, E.M. (1995). Electronics and the dim future of the university. Science, 270, 247-249.

Oost, H., Holleman, W., Berg, I. van den, Thoolen, B., \& Milius, J. (1998). Naar een interpretatie van academische vorming. Utrecht: Universiteit Utrecht, IVLOS.

Piederit, J.J. (1996). Where universities have gone wrong. Wall Street Journal, July 30 , editorial page.

Researchcentrum voor Onderwijs en Arbeidsmarkt (1999). De arbeidsmarkt naar opleiding en beroep tot 2004. Maastricht: Roa, Faculteit der Economische Wetenschappen en Bedrijfskunde.

Rowley, D.J., Lujan, H.D., \& Dolence, M.G. (1998). Strategic choices for the academy. How demand for lifelong learning will re-create higher education. San Francisco: Jossey-Bass.

Salomon, G. (1999). De universiteit en de uitdagingen van het informatietijdperk. Rede uitgesproken aan de Katholieke Universiteit Leuven, 2 februari 1999.

SER (1995). Kennis en economie. Publikatie nr. 4. Den Haag: Sociaal Economische Raad.

Sveiby, K.E. (1998). Kennis als bedrijfskapitaal. Amsterdam / Antwerpen: Uitgeverij Contact.

TERI (The Education Resources Institute) (1996). Life after forty. Washington, D.C.: Institute for Higher Education Policy.

Wilshire, B. (1990). The Moral Collapse of the University. Albany: State University of New York Press. 


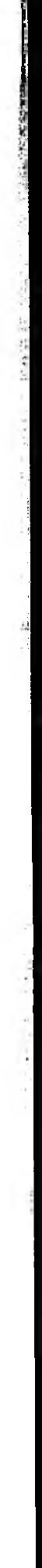


P.

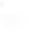

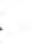




\title{
Studeren voor Nieuwe geleerden: Over de Kwaliteit van het Leren
}

\author{
Rede \\ In verkorte vorm uitgesproken bij de aanvaarding van het ambt van \\ hoogleraar Onderwijskunde aan de Faculteit der \\ Gezondheidswetenschappen van de Universiteit Maastricht op vrijdag
}

17 november 2000

Door

Dr. Jan Vermunt 
Geachte rector,

Dames en heren,

Onlangs is een boek verschenen onder redactie van onder meer mijn promotor RobertJan Simons, met als titel 'New Learning', Nieuw Leren. Hiermee bedoelen de redacteuren nieuwe leeruitkomsten, nieuwe soorten leerprocessen, en nieuwe onderwijsmethoden die zowel door de maatschappij worden vereist als door hedendaagse psychologische en onderwijskundige theorieën worden benadrukt.

De samenleving van vandaag wordt gekenmerkt door een enorme groei in de beschikbare kennis en informatie. Vroeger waren opleidingen erop gericht studenten kennis van een vakgebied bij te brengen waarmee ze voor de rest van hun leven een beroep konden uitoefenen. Tegenwoordig is het onmogelijk om bij het afstuderen een vakgebied volledig te beheersen. $\mathrm{Er}$ is te veel om te weten en te kunnen, en wat we vandaag weten en kunnen is over een paar jaar weer achterhaald. Simons en zijn collega's pleiten er dan ook voor dat afgestudeerden vooral moeten beschikken over vaardigheden die het mogelijk maken het leven lang door te leren, zelfstandig te denken, samen te werken en het eigen leren en denken te sturen (Simons, Van der Linden \& Duffy, 2000). Nieuwe geleerden zijn dus mensen die beschikken over goede kennis van het vakgebied en over doorgroeicompetentie: de kennis, houding en vaardigheden die nodig zijn om ook na de opleiding, zelfstandig en in samenwerking met anderen, de eigen kennis van het vakgebied voordurend op peil te houden en de eigen beroepscompetenties voortdurend te ontwikkelen. Nieuwe geleerden raken nooit uitgeleerd! Maar hoe kun je nu studeren voor iemand die nooit raakt uitgeleerd?

In deze oratie wil ik verkennen welke onderwijsvormen geschikt zijn voor dit nieuwe leren. Ik zal daarbij de vraag aan de orde stellen in hoeverre het onderwijsmodel waarmee de Universiteit Maastricht faam heeft verworven, probleemgestuurd onderwijs (pgo), voldoet om deze nieuwe vormen van leren te realiseren. Voor zover pgo naar mijn oordeel hieraan niet voldoet, zal ik trachten aan te geven op welke punten het onderwijsmodel renovatie behoeft om bij de tijd te blijven.

\section{De kwaliteit van het leren}

De laatste decennia zien we dat in het denken over de kwaliteit van onderwijs het leerproces van de studenten een steeds centralere plaats 
inneemt. Vroeger spraken we vooral van goed onderwijs als de docent de stof goed had uitgelegd. Of studenten de stof ook goed hadden begrepen was vooral hun eigen verantwoordelijkheid. Tegenwoordig spreken we pas van goed onderwijs als de docent de student tot goed leren heeft gebracht. Maar wat is nu goed leren?

De afgelopen jaren heb ik met collega's en promovendi een reeks onderzoeken gedaan naar de wijze waarop studenten leren en naar factoren die daarop van invloed zijn. Hierbij komen steeds weer vier kwalitatief verschillende vormen van leren naar voren. Reproductief leren houdt in dat studenten de stof grondig, tot in detail bestuderen en proberen te onthouden zodat zij die op een toets kunnen reproduceren. $\mathrm{Bij}$ betekenisgericht leren probeert een student samenhangen te ontdekken in het studiemateriaal, overzicht te krijgen, er kritisch tegenover te staan en de stof zo goed mogelijk te begrijpen. Een student die toepassingsgericht leert probeert zich vooral de stof concreet voor te stellen en na te denken over hoe die gebruikt kan worden in de praktijk. Ongericht leren betekent dat studenten eigenlijk niet goed weten hoe ze hun studie aan moet pakken. Ze vallen bijvoorbeeld terug op vroegere leergewoonten van de middelbare school die in het hoger onderwijs niet meer werken. In discussies met docenten blijkt steeds weer dat betekenis- en toepassingsgericht leren als 'goed' worden beschouwd in het hoger onderwijs en ongericht leren als ongewenst. De discussies raken vaak verhit wanneer men praat over de waarde van het reproductiegerichte leren: sommigen vinden dat een noodzaak, anderen verwerpelijk.

Welke wijze van leren studenten praktiseren in hun studie blijkt samen te hangen met hun opvattingen over leren en onderwijs (hun leerconcepties) en hun studiehouding en -motivatie (hun leeroriëntatie). Dit kan wellicht verklaren waarom Vermetten in haar promotieonderzoek vond dat de manier van leren redelijk stabel is over de tijd en over verschillende cursussen heen, maar ook zeker niet onveranderlijk (Vermetten, Lodewijks \& Vermunt, 1999). Dit laatste betekent dat de onderwijsvorm er ook toe doet.

Een andere dimensie waarop leerprocessen geschaald kunnen worden is de mate van zelfstandigheid waarmee ze worden uitgevoerd. Allerlei leer- en regulatie-activiteiten kunnen in meer of mindere mate door de student zelf of door de onderwijsomgeving, zoals docenten, tutoren, computers, enzovoort, worden verricht. Van zelfstandig leren is sprake wanneer studenten vooral zèlf die leer- en regulatie-activiteiten uitvoeren.

Van samenwerkend, of coöperatief leren, is sprake wanneer studenten met elkaar samenwerken bij het leren. Het onderwijs kan 
daarbij meer of minder sturend zijn, en de mate van zelfstandigheid die van groepjes samenwerkende studenten wordt verwacht kan dan ook variëren. Alléén leren staat dus tegenover samenwerkend leren en is niet hetzelfde als zelfstandig leren.

Het laatste decennium heb ik met collega's en promovendi onderzoek gedaan naar allerlei facetten van de leerprocessen van studenten in het hoger onderwijs, een onderzoeksdomein dat in het Engels bekend staat als 'student learning in higher education'. In kwalitatieve en kwantitatieve studies hebben we onder meer onderzocht van welke cognitieve, affectieve en metacognitieve leer- en denkstrategieèn studenten gebruik maken bij hun studie en hoe dat gebruik samenhangt met persoonsgebonden en omgevingsgebonden factoren (Vermunt, 1996, 1998). In haar promotieonderzoek is Yvonne Vermetten nagegaan in hoeverre het strategiegebruik door studenten consistent dan wel variabel is over de tijd en over situaties heen, en in hoeverre dat strategiegebruik wordt beïnvloed door factoren als doeloriëntatie, persoonlijkheid, perceptie van de leeromgeving en interpretatie van de didactische maatregelen (Vermetten, 1999). Clara Ajisuksmo vergeleek Nederlandse en Indonesische studenten in hun studiepatronen en stelde culturele verschillen vast in de wijze waarop deze groepen studenten studeren en hun leerprocessen reguleren (Ajisuksmo \& Vermunt, 1999). Gonny Schellings richtte zich op één bepaalde cognitieve leerstrategie, het selecteren van informatie, en constateerde individuele verschillen in de wijze waarop mensen zich aanpassen aan verschillende typen leertaken (Schellings, Van HoutWolters \& Vermunt 1996). Ida Oosterheert identificeerde de leerpatronen van studenten in duale opleidingen en richtte zich op de rol van emoties bij dit leren (Oosterheert \& Vermunt, in press). Anneke Zanting onderzocht of en op welke wijze studenten in een duale lerarenopleiding op hun stagescholen de praktijkkennis van ervaren docenten proberen te benutten (Zanting, Verloop \& Vermunt, in press). En recentelijk heeft het onderzoek van Ilse van Eekelen duidelijk gemaakt dat ervaren docenten niet, zoals vaak wordt gedacht, na verloop van tijd ophouden met nieuwe dingen te leren, maar dat hun leren wel veel minder gepland verloopt dan in onderwijssituaties het geval is (Van Eekelen, Boshuizen \& Vermunt, submitted). In een recente studie van Nico Verloop en mijzelf konden we een aantal vormen van dissonantie identificeren tussen de studieaanpak, de studieopvaltingen en de studiemotieven van studenten: het fenomeen dat het studiegedrag niet overeenkomt met de studieopvattingen en -motieven. Studenten bij wie dit het geval was boekten vaak slechte studieprestaties (Vermunt \& Verloop, 2000). 
We hebben tot nu toe verschillende kwaliteiten van leren kunnen onderscheiden: ongericht, reproductiegericht, betekenisgericht, toepassingsgericht, zelfstandig en samenwerkend. Uit de Keuzegids Hoger Onderwijs (Steenkamp, Maljaars \& Blankesteijn, 2000) en de Elsevier-special 'De beste studies' (2000) blijkt dat studenten het over het algemeen erg waarderen wanneer ze zelfstandig aan de slag kunnen gaan met taken of opdrachten die zijn ontleend aan de praktijk.

\section{Probleemgestuurd onderwijs en de kwaliteit van het leren}

Is probleemgestuurd onderwijs zoals bijvoorbeeld gepraktiseerd aan de Universiteit Maastricht (UM) een geschikte ondenwijsvorm om mensen te brengen tot nieuwe geleerden, tot mensen die nooit raken uitgeleerd? Laten we eens kijken.

Voor de mensen van buiten de Universiteit Maastricht is het misschien goed even in een paar zinnen te schetsen wat probleemgestuurd onderwijs is. In pgo werken studenten in kleine groepen van ongeveer tien personen (de onderwijsgroep) aan het begrijpen en verklaren van problemen. Startpunt voor het leren is telkens een probleem: een korte beschrijving van een verschijnsel waarover studenten kennis moeten verwerven. In de onderwijsgroep analyseren studenten het probleem en formuleren ze leerdoelen: vragen waarop ze door zelfstudie antwoord moeten vinden. Na deze zelfstudie komen de studenten weer bij elkaar en rapporteren ze wat ze over het probleem hebben geleerd. Tevens worden onduidelijke zaken verhelderd en wordt de verkregen informatie bediscussieerd, kritisch beoordeeld en geïntegreerd. Tijdens het werken in de onderwijsgroep worden studenten begeleid door een tutor, die tot taak heeft het leer- en groepsproces te faciliteren (Schmidt \& Moust, 1998). Meestal komt de onderwijsgroep twee keer per week bij elkaar; tijdens een bijeenkomst wordt over éen probleem gerapporteerd en wordt een volgend probleem voorbesproken. Naast deze groepsbijeenkomsten volgen studenten ook practica, vaardighedenonderwijs en enkele hoorcolleges. Aan het einde van een onderwijsperiode, die zo'n 5 tot 8 weken duurt, volgt de toets, waarna een nieuwe onderwijsperiode met een ander thema start. Deze vorm van pgo zal ik in het vervolg 'klassiek pgo' noemen.

Welke vormen van leren bevordert dit probleemgestuurd onderwijs nu? Pgo is een vrij gestructureerde kleinschalige onderwijsmethode, waardoor ongericht leren door studenten wordt tegengegaan. In zijn originele opzet is pgo ook expliciet gericht op het ontmoedigen van reproductiegericht, toetsgericht leren Nan Berkel, 
Nuy \& Geerligs, 1995). Pgo lijkt ook zeker gericht op het bevorderen van diep, betekenisgericht leren, omdat studenten verklaringen en dergelijke moeten zoeken voor meestal betekenisvolle problemen. En pgo bevordert tot op zekere hoogte toepassingsgericht leren, omdat de taken en problemen zijn ontleend aan de praktijk. Overigens hangt een en ander sterk af van de kwaliteit en variëteit van de taken en problemen die worden gebruikt. Wat pgo zeker bevordert is samenwerkend leren, omdat de studenten in de ondenwijsgroep samenwerken aan het analyseren, bediscussiëren, verklaren, enzovoort van het probleem. En op het eerste gezicht bevordert pgo ook zelfstandig leren, omdat studenten bijvoorbeeld zelf leerdoelen moeten formuleren en relevante bronnen moeten zoeken en bestuderen. Een ideale onderwijsmethode dus voor het nieuwe leren? Of toch niet? Laten we nog eens wat beter kijken.

Onderwijs dat erop is gericht studenten te leren steeds zelfstandiger te leren en denken wordt gekenmerkt door een geleidelijke verschuiving in de taakverdeling in het leerproces van het onderwijs naar de studenten (Vermunt \& Lowyck, 2000; Vermunt \& Verschaffel, 2000). Aanvankelijk wordt een expliciete externe sturing aangeboden aan de studenten. Vervolgens wordt de geboden hulp en ondersteuning geleidelijk teruggetrokken. Tegelijkertijd wordt studenten geleerd hoe ze deze controle over hun leerprocessen zelf kunnen verrichten. Leren zelfstandig te leren en zelfstandig te denken betekent dan een geleidelijke overdracht van leerfuncties van het onderwijs naar de studenten, een graduele overgang van externe naar interne sturing van het leren (zie figuur 1). Kenmerkend is dat de onderwijsmethode meeverandert met de toenemende zelfstandigheid van de studenten. Deze worden daardoor steeds weer opnieuw uitgedaagd een stapje verder te komen in hun zelfstandig leren en denken. Uiteindelijk doel is dat studenten bij hun afstuderen doorgroeicompetent zijn: bereid en in staat ook na het afsluiten van de onderwijsloopbaan zich voortdurend te blijven ontwikkelen in hun vakgebied en nooit uitgeleerd te raken. 
Sturen van

leerprocessen

vaak

zelden

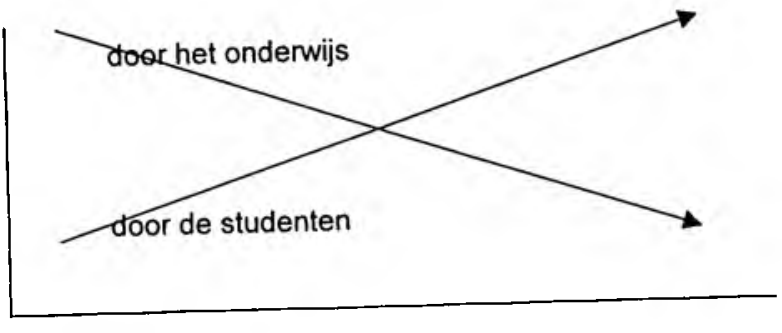

Verloop in de tijd

Figuur 1. Geleidelijke overdracht van de sturing over het leerproces van het onderwijs (docent, tutor, boek, computer e.d.) naar de studenten

Kenmerkend voor klassiek pgo zoals dat op vele plaatsen wordt uitgewerkt is dat de onderwijsmethode niet meeverandert met de toenemende zelfstandigheid van de studenten. Het stramien van twee groepsbijeenkomsten per week, twee problemen per week, laken van een bepaalde grootte, onderwijsblokken van een vast aantal weken, onderwijsgroepen van een vaste grootte, de sturende rol van de tutor, en de zevensprong om het probleemgestuurde werken te structureren, blijven door de jaren heen ongeveer gelijk. Voor eerstejaars studenten betekent deze werkwijze over het algemeen nog een flinke uitdaging; zij waren immers op de middelbare school niet gewend aan deze mate van zelfstandig leren: zelf leerdoelen formuleren, bronnen opzoeken, de leerresultaten terugrapporteren, en dergelijke. En zoals het hoort worden vele studenten gedurende het eerste studiejaar beter in deze vaardigheden die passen bij de mate van zelfstandigheid die van ze wordt verwacht in de probleemgestuurde onderwijsmethode. Maar na het eerste studiejaar verandert er weinig aan de methode, wordt de werkwijze een routine en houdt de uitdaging op te bestaan (zie figuur 2 ). 
Sturen van

leerprocessen

vaak

zelden

door klassiek pgo

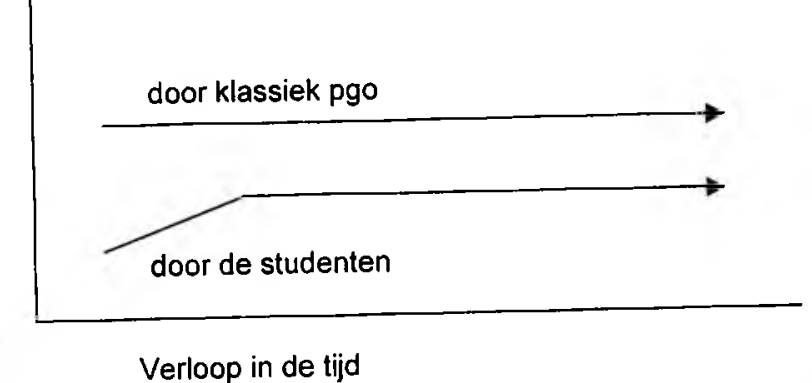

Figuur 2. Constante sturing van het leerproces van studenten door klassiek probleemgestuurd onderwijs

\section{Onderwijsvernieuwing}

Het basisidee van probleemgestuurd onderwijs, namelijk dat studenten door actief leren, aan de hand van levensechte problemen, hun kennis verwerven, is nog net zo actueel als toen de methode 25 jaar geleden aan de Universiteit Maastricht werd ingevoerd. Wat mijns inziens revitalisering en renovatie behoeft zijn de 'handen en voeten' waarmee dit idee in de praktijk wordt vormgegeven. Een zevensprong, twee bijeenkomsten per week, tamelijk kleine problemen die met twee dagen zelfstudie kunnen worden verklaard of opgelost, taken die door docenten worden bedacht, de groepsgrootte van ongeveer 10 studenten, de aard en mate van sturing door de tutor, zilin allemaal bepaalde uitwerkingen van dit basisidee die echter vaak tot doctrine worden verheven. Probleemgestuurd onderwijs met zijn Maastrichtse 'handen en voeten' is éen vorm van het bevorderen van zelfstandig werken, naast andere mogelijk vormen. Bouhuys (2000) stelt bijvoorbeeld dat de zevensprong oorspronkelijk vooral was bedoeld om studenten die weinig ervaring hadden met pgo een houvast te bieden.

Toen ik enkele jaren geleden in San Diego het jaarlijkse congres van de American Educational Research Association bijwoonde werd ik geboeid door een sessie waarin een duale opleiding was vormgegeven volgens probleemgestuurd leren. Leraren-in-opleiding gaven les op een school en volgden onderwijs op de universiteit. Dat onderwijs op de 
universiteit was probleemgestuurd van aard, maar de problemen werden niet door de universitair docenten bedacht maar door de studenten zelf ingebracht en waren gebaseerd op zelf ervaren problemen in de praktijk. Sommige van deze problemen waren klein, andere groot. In de onderwijsbijeenkomsten werden zo'n probleem bediscussieerd en vanuit de verschillende praktijkervaringen van de aanwezigen geanalyseerd. Voor de aspecten waar de groep nog geen raad mee wist werden leerdoelen geformuleerd gevolgd door literatuurstudie en een rapportagebijeenkomst. Essentieel verschil met klassiek pgo is dus dat het 'eigendom' (ownership) van het probleem waaraan wordt gewerkt bij de studenten ligt.

Afgelopen zomer nam ik in Helsinki deel aan een internationale conferentie over Innovations in higher education. Daar viel mij op hoe creatief sommige docenten nieuwe handen en voeten voor probleemgestuurd onderwijs hadden bedacht. Zo is met name voor grotere opleidingen het aantal benodigde tutoren al snel een probleem, ook in het Maastrichtse geen onbekend fenomeen. Aan de psychologieopleiding van de Universiteit van Helsinki werd bijvoorbeeld de regel losgelaten dat elke bijeenkomst van een onderwijsgroep door een tutor moet worden begeleid. Er werden studiegroepen gevormd van ongeveer vier studenten. Deze groepen werkten zonder docent of tutor aan het verklaren van problemen die in één bijeenkomst per week onder begeleiding van een docent werden geïntroduceerd, besproken en gerapporteerd. Afhankelijk van het doel van de bijeenkomst werd de grootte van de studentengroep gevarieerd in veelvouden van vier (Nieminen \& Pruuki, 2000).

Aan de Universiteit van Nijmegen heeft de Faculteit der Beleidswetenschappen een mix geïntroduceerd van probleemgestuurd onderwijs en projectonderwijs, waarin voor het verwerven van academische vaardigheden een belangrijke plaats is ingeruimd (Van den Bosch, Gerritsen \& Meijssen, 1998). En aan onze eigen universiteit wordt aan de Faculteit Algemene Wetenschappen en in verschillende blokken van de Faculteit der Gezondheidswetenschappen gewerkt en geëxperimenteerd met diverse vormen van projectonderwijs (zie bijv. Kirschner, 2000; Machiels \& Van Baak, 2000).

\section{Zeven scenario's}

Laten we eens een aantal onderwijsvormen nader bekijken op de mate van zelfstandigheid, eigen initiatief en verantwoordelijkheid die van studenten worden verwacht. 


\section{Traditioneel onderwijs}

Dit type onderwijs kwam in de jaren zeventig tot negentig veel voor op de universiteiten, en was de dominante onderwijsvorm in de tijd dat de Universiteit Maastricht startte met probleemgestuurd onderwijs. In dit traditioneel onderwijs werd de studiestof volledig door de docent bepaald, vaak niet in de vorm van casussen, problemen of opdrachten, maar in de vorm van boeken of hoofdstukken die gekend moesten worden. In hoorcolleges werd de stof uitgelegd en toegelicht. Soms waren er ook werkcolleges waar de stof werd uitgediept, problemen werden opgehelderd, opdrachten werden nabesproken, enz. Aan het einde van een semester, of van een heel studiejaar, was er een tentamenperiode waarin alle vakken van de afgelopen periode werden getentamineerd. In de Bètastudies was er bovendien sprake van veel practica. Studiestof, leerdoelen, studiebronnen, criteria voor de leerresultaten, toetsing en feedback waren dus geheel in handen van de docent. Alleen bij het kiezen van de leeractiviteiten hadden studenten enige vrijheid.

\section{Klassiek probleemgestuurd onderwijs.}

In deze vorm van onderwijs verlopen leerprocessen ongeveer zoals hierboven reeds is geschetst. Studenten werken in kleine groepen van ongeveer tien personen aan het begrijpen en verklaren van problemen. In de onderwijsgroep analyseren studenten een probleem en formuleren ze leerdoelen. Na zelfstudie komen ze weer bij elkaar en rapporteren wat zij over het probleem hebben geleerd. Tijdens het werken in de onderwijsgroep worden studenten begeleid door een tutor. Meestal komt de onderwijsgroep twee keer per week bij elkaar; tijdens zo'n bijeenkomst wordt over één probleem gerapporteerd en wordt een volgend probleem voorbesproken. Naast deze groepsbijeenkomsten volgen studenten ook practica, vaardighedenonderwijs en enkele hoorcolleges. Aan het einde van een onderwijsperiode volgt de toets.

\section{Pgo met zelfsturende studiegroepen}

In dit scenario wordt meer zelfstandigheid en initiatief verwacht van studenten dan in klassiek pgo en een complexere vorm van samenwerking. De moeilijkheidsgraad van de werkvorm is dus groter. Er worden groepen gevormd van ongeveer vier studenten die werken aan studietaken van gevarieerde aard, waaronder het begrijpen en 
verklaren van problemen. Ze werken hieraan volgens de principes van coöperatief leren: er is sprake van kleine groepen, positieve wederzijdse afhankelijkheid, individuele aanspreekbaarheid, en gelijkwaardige bijdrage (Haitink, 1996; Bolhuis \& Kluvers, 1998). Zij werken zonder begeleiding van een tutor, maar nemen zelf om beurten de rol van voorzitter en notulist op zich. Eén keer per week is er een onderwijsbijeenkomst onder begeleiding van een docent, waar enkele van dergelijke studiegroepen worden samengevoegd. In deze bijeenkomst worden de leervorderingen besproken, moeilijkheden opgelost, producten van de verschillende groepen vergeleken, onduidelijke zaken verhelderd en wordt de verkregen informatie bediscussieerd, kritisch beoordeeld en geintegreerd. Tevens wordt het studiewerk van de volgende week voorbesproken. In vergelijking met het pgo uit scenario 2 is er sprake van grotere en complexere problemen, meer zelfstandigheid als studiegroep, taken die niet noodzakelijk in één week afgerond hoeven te worden, en naast individuele ook groepsproducten die opgeleverd moeten worden. Naast deze leerlijn volgen studenten ook practica, vaardighedenonderwijs en enkele hoorcolleges. Toetsing gebeurt ook aan de hand van de schriftelijke of andere producten die studenten, individueel en in groepsverband, maken tijdens de rit als resultaat van het werken aan de taken.

\section{Projectonderwijs}

Projectonderwijs is weer een trede verder op de ladder van zelfstandig leren en denken. Vertrekpunt van het leerproces bij projectgestuurd leren is een projectopdracht of probleem. Het betreft authentieke, levensechte opdrachten die vaak direct aan de praktijk zijn ontleend. Soms kunnen studenten kiezen uit een aantal opdrachten of problemen om aan te werken. Studenten werken in kleine groepen (meestal 4-5 studenten) zelfstandig aan de opdracht. Voorafgaand aan, of tegelijk met het eigenlijke projectwerk is vaak een fase van kennisverwerving voorzien door middel van andere werkvormen zoals bijvoorbeeld pgo of colleges. De kennis, inzichten en vaardigheden van het vakgebied die op die wijze zijn verworven moeten worden toegepast op de projectopdracht. Studenten werken zelfstandig in de projectgroepen aan de opdracht zonder begeleiding van een docent. Dikwijls vindt éen keer per week een bijeenkomst plaats onder begeleiding van een docent, waarin de voortgang wordt besproken, moeilijkheden worden opgelost en wordt vooruitgekeken naar de volgende projectfase. Het project verloopt in fasen die steeds worden afgesloten door 
beoordelingsmomenten van proces en product (zie bijv. Van Woerden, 2000). Het project resulteert in een groepsproduct, bijvoorbeeld een ontwerp, een advies, een plan, een voorstel, en dergelijke. Aan het einde van een projectblok worden de gemaakte producten vaak gepresenteerd voor de gehele groep studenten in aanwezigheid van docenten en soms ook opdrachtgevers. Het product wordt beoordeeld aan de hand van tevoren opgestelde criteria. Ook wordt de projectpresentatie vaak beoordeeld op inhoud en vorm. Soms wordt de kennisverwerving afzonderlijk getoetst. Soms ook wordt gebruik gemaakt van individuele portfolio's om de individuele leerprestaties en de bijdrage van de afzonderlijke studenten aan het groepsproces en groepsproduct te kunnen beoordelen (zie bijv. Westerterp et al., 2000).

\section{Zelfgestuurd specialisatieleren}

In de hogere jaren van een studie in het hoger onderwijs komen vaak vormen voor van zelfgestuurd specialisatieleren waarbij gebruik wordt gemaakt van individueel begeleide studietaken (zie bijv. Hamaker, 2000). Een bekend voorbeeld hiervan is de afstudeerscriptie in de vorm van een verslag van empirisch, literatuur- of bronnenonderzoek. Studenten hebben dan de gemeenschappelijke basiskennis verworven en specialiseren zich in bepaalde facetten van het vakgebied, vaak op basis van individuele interessen. Soms ook werken twee of drie studenten samen aan een dergelijk project wanneer er studenten voorhanden zijn met gemeenschappelijke interessen. Kenmerkend is dat de projecten vaak een wat langere duur hebben ( 3 - 6 maanden) en kennisverwerving over het specifieke onderwerp onderdeel uitmaakt van het project. Een of twee docenten fungeren als begeleider. Studenten schrijven een projectvoorstel waarin de probleemstelling, doelen, activiteiten, te gebruiken bronnen, beoogd projectresultaat, en de wijze van begeleiding worden beschreven. In wezen komt dit neer op een studietaak of projectopdracht die ze voor zichzelf formuleren. Deze wordt besproken met de begeleider, en op grond van diens commentaar passen studenten hun voorstel aan voordat ze tot uitvoering kunnen overgaan. Verdere begeleiding is vaak op maat, afhankelijk van bijvoorbeeld de projectfase waarin een student zich bevindt, de moeilijkheidsgraad van het project en de behoefte aan begeleiding c.q. de mate van zelfstandigheid waartoe een student in staat is. Na afloop wordt het projectproduct beoordeeld aan de hand van tevoren opgestelde criteria. Soms worden in de eindbeoordeling ook procescriteria betrokken. 


\section{Duaal leren.}

Bij duale vormen van leren combineren studenten de studie aan de universiteit of hogeschool met het leren uit de praktijk (vgl. Kirschner, 2000). De universitaire lerarenopleidingen in Nederland zijn bijvoorbeeld allemaal opgezet volgens deze ondenwijsvorm. Deze éénjarige, postdoctorale opleidingen zijn als het ware een vijfde studiejaar. Vanaf het begin tot het einde lopen studenten (docenten-in-opleiding: dio's) stage op een school voor ongeveer de helft van hun studietijd. Daar observeren ze lessen van ervaren docenten, geven ze zelf lessen, doen praktijkonderzoek, begeleiden leerlingen, overleggen met hun stagebegeleider en draaien mee in de schoolorganisatie als geheel. De andere helft van de studietijd wordt gevormd door het theoretisch deel van de studie. Studenten hebben zo drie belangrijke bronnen om van te leren: hun eigen praktijkervaringen, de praktijkkennis van de stagebegeleider en andere docenten op school, en de theorie (zie bijv. Zanting et al., in press). De kernvraag bij zo'n type opleiding is hoe de verschillende soorten kennis die studenten op deze wijze verwerven tot een geïntegreerd kennisbestand kunnen worden samengebracht. Dit vereist een ander onderwijsconcept dan bij een enkelvoudig, niet-duaal traject. $Z o$ is de volgorde waarin de stof aan de orde dient te komen niet meer vooral gebaseerd op stoflogische argumenten, maar veel eerder op 'concerns' en leerbehoeften die studenten in de praktijk ontwikkelen. $\mathrm{Bij}$ verkeerde didactieken ontwikkelen studenten drie verschillende kennisbestanden die nauwelijks met elkaar zijn verbonden. In Nederland heeft met name Korthagen (bijv. 1998) baanbrekend werk verricht op dit terrein, waarbij hij een centrale rol toekent aan reflectie op praktijkervaringen bij het integreren van theorie- en praktijkkennis en het ontwikkelen van een subjectieve theorie over het vak of beroep. Veel huidige Mastersopleidingen zijn ook opgezet volgens dit model. Boud (1999) spreekt in dit verband van work-based learning. Evaluatie van de leervorderingen gebeurt vaak met behulp van portfolio's (Van Tartwijk \& Wubbels, 2000). Bij een probleemgestuurd opzet van het theoriedeel van de opleiding brengen studenten casussen of problemen die ze in de praktijk hebben ervaren, in een onderwijsgroep in, die als startpunt in een leercyclus fungeren.

\section{Autodidactisch leren}

Bij deze vorm van leren bepaalt de lerende zelf alle aspecten van zijn of haar leerproces: de problemen waarover wat wordt geleerd, de doelen waarmee wordt geleerd, de leeractiviteiten, te raadplegen bronnen, het gewenste leerresultaat en de beoordeling en feedback. Hij of zij is als 
het ware de eigen docent. Wel kan iemand er voor kiezen bepaalde aspecten van dit leren met collega's of anderen te delen, en elkaar bijvoorbeeld feedback te geven. $\mathrm{Er}$ is dan sprake van collegiaal ondersteund leren (Tigchelaar en Melief, 1997) of peer coaching (Bergen, 1996). Volledig autodidactisch leren zal in het onderwijs, althans in het formele curriculum, nauwelijks voorkomen, al is het maar dat de leerprestaties van studenten uiteindelijk altijd door de opleiding worden beoordeeld die daarmee garant staat voor de kwaliteit van de door haar afgegeven diploma's.

\section{De opbouw van een curriculum in termen van onderwijsvormen}

Wanneer we bovenbesproken scenario's samenvatten in de wijze van sturing die wordt uitgeoefend over het leren van studenten ontstaat ongeveer het volgende beeld (zie Tabel 1).

Tabel 1. De wijze van sturing van de leerprocessen van studenten in zeven' onderwijsscenario's op een dimensie van docentgestuurd naar studentgestuurd.

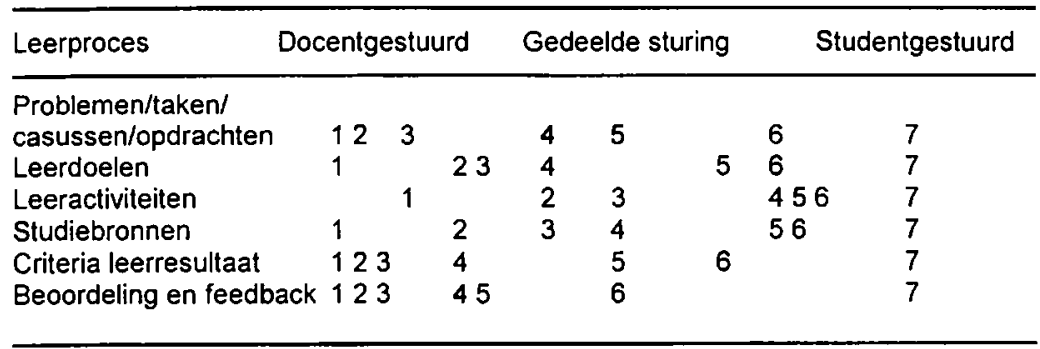

1: 1 = traditioneel onderwijs; 2 = klassiek pgo; 3 = pgo met zelfsturende studiegroepen; 4 = projectonderwijs; $5=$ zelfgestuurd specialisatieleren; $6=$ duaal leren; 7 = autodidactisch leren.

Alle laatste zes onderwijsscenario's bevorderen actief leren aan de hand van problemen, casussen of opdrachten, maar ze klimmen op in de mate van zelfstandigheid die van studenten wordt vereist en in de omvang en complexiteit van de problemen waaraan ze werken. Ze variëren in de aard van de samenwerking die van studenten wordt verwacht. Van alle aspecten van het leerproces worden leeractiviteiten het eerst in handen van de studenten gelegd, beoordeling en feedback het laatst. De middelste vijf scenario's zijn kleinschalig en 
studentgericht, en voldoen daarmee aan twee belangrijke profielkenmerken van het UM-onderwijs. Van deze vijf scenario's doet klassiek pgo het minst een beroep op zelfstandig leren. Wanneer we het belangrijk vinden dat studenten steeds zelfstandig leren te leren en denken, lijkt er dus veel voor te zeggen de onderwijsmethode te laten meeveranderen met de toename in zelfstandigheid die steeds wordt bereikt. Dit leidt tot een curriculum dat getypeerd wordt door een geleidelijke, systematische afnemende externe sturing vanuit het onderwijs en een toenemende zelfsturing door de studenten (overdracht van sturing). In een vijfjarig curriculum zou in de opeenvolgende studiejaren dus telkens één scenario dominant kunnen zijn: in het eerste studiejaar klassiek pgo, in het tweede jaar pgo met zelfsturende studiegroepen, in het derde projectonderwijs, in het vierde zelfgestuurd specialisatieleren en in het vijfde studiejaar duaal leren. Zonder dit principe overigens al te rigide toe te passen, variatie is immers de bron van alle leren (Marton, 1999). Zo kan kennismaken met de beroepspraktijk in de vorm van kleine duale trajecten ook in eerdere studiejaren al zeer nuttig zijn in sommige opleidingen (vergelijk het medisch curriculum), en gaan zelfsturende studiegroepen geruisloos over in projectteams van projectonderwijs. Anderzijds kan klassiek pgo bij een stuk moeilijke en nieuwe studiestof ook in het derde jaar wellicht de beste onderwijsvorm zijn.

Op deze wijze wordt op twee manieren gewerkt aan de ontwikkeling van zelfstandigheid in het leren van studenten (Van Loosbroek \& Willems, 2000). Ze worden in de loop van het curriculum geconfronteerd met steeds grotere en complexere taken, problemen of opdrachten, waarbij ze een beroep moeten doen op een steeds groter scala aan verworven competenties (vgl. Ten Cate, 1999). Ten tweede neemt de externe sturing in de taken en onderwijsvormen af waardoor studenten zelf een steeds grotere rol krijgen in het bepalen van de problemen waaraan wordt gewerkt, de leerdoelen waarmee wordt gewerkt, het kiezen van leeractiviteiten, het zoeken van geschikte bronnen, het bepaten van de criteria waaraan de leerresultaten moeten voldoen, het bewaken van leervorderingen en het beoordelen van de leerresultaten.

Een degelijke onderwijsvisie hebben we elders procesgericht ondenwijs genoemd, omdat het is gericht op de processen van kennisverwerving en kennisgebruik (zie Simons, 1997; Volet, McGill \& Pears, 1995; Vermunt \& Verschaffel, 2000). Het is gebaseerd op een analyse van de wisselwerkingen die kunnen optreden tussen de wijze waarop het onderwijs wordt gegeven en de wijze waarop studenten hun studie aanpakken (Vermunt \& Verloop, 1999). Het wordt gekenmerkt 
door een geleidelijke afbouw van de sturing over leerprocessen die van het onderwijs uitgaat en doet in toenemende mate een beroep op zelfsturing van leerprocessen door studenten, individueel en in groepsverband. Het is mijns inziens een onderwijsvisie die goede oplossingen biedt voor de onvrede die leeft onder UM-medewerkers met het klassieke pgo als enig onderwijsmodel voor een heel curriculum (zie bijv. Kuipers, 2000). Het is bovendien een visie die perspectief biedt om tegelijkertijd de sterke kant van het Maastrichtse onderwijs, volgens de Keuzegids Hoger Onderwijs 'leren zelfstandig te denken', te verbeteren of wellicht pas echt te realiseren.

\section{Bachelor - Master}

Als gevolg van de Bologna-verklaring, waarin ministers van ondenwijs van 29 Europese landen vorig jaar hebben afgesproken hun systemen van hoger onderwijs beter op elkaar af te stemmen, wordt momenteel op vele plaatsen in het Nederlandse hoger onderwijs nagedacht over een herziening van het curriculum in termen van het Bachelor - Master model: een (driejarige) Bachelorfase die veelal breed van opzet zal zijn, gevolgd door een (één à tweejarige) Masterfase met een meer specialistisch karakter. Keuzes moeten hierbij gemaakt worden ten aanzien van onder meer: de eindtermen van beide fasen; de breedte versus smalte van beide fasen; de keuzevrijheid voor studenten wat betreft hun studiepakket; het al dan niet werken volgens een major/minor-systeem; de onderwijs- en toetsvormen; het civiele effect van het Bachelordiploma; en de open of gesloten toelating voor de Masterfase.

Het kiezen van onderwijs- en toetsvormen dient mijns inziens volgens de hiervoor beschreven onderwijsprincipes te geschieden. Dit betekent klassiek pgo, pgo met zelfsturende studiegroepen en projectonderwijs achtereenvolgens als dominante onderwijsvormen in de Bachelorfase, zelfgestuurd specialisatieleren en duaal leren als dominante onderwijsvormen in de Masterfase, en een toename in grootte en complexiteit van de problemen waaraan wordt gewerkt. Wanneer met het Bachelordiploma ook een civiel effect wordt beoogd, dienen in de Bachelorfase ook praktijkgerichte, bij voorkeur duale (stage) onderdelen verwerkt te worden. Keuzevrijheid voor studenten bevordert over het algemeen een diepere verwerking van de studiestof (Ramsden, 1992) en zelfstandigheid. De eindtermen van 'Colleges', brede Bachelors waarin studenten een variëteit aan vakgebieden bestuderen, kunnen voor een deel in termen van cognitieve, regulatieve 
en affectieve vaardigheden worden geformuleerd ('academisch leren denken').

\section{Informatie- en Communicatietechnologie (ICT)}

Uiteraard dient in hedendaagse onderwijsvormen overal waar dat mogelijk en nuttig is, gebruik gemaakt te worden van de mogelijkheden die moderne informatie- en communicatietechnologie biedt. Daarbij dient wel zorgvuldig te worden nagedacht over de functie die ICT bij het leren van studenten moet vervullen: een inhoudsfunctie, informatiefunctie, communicatiefunctie, diagnostische functie, leerfunctie of toetsfunctie (vergelijk Collins \& Van der Wende, 1999; Mirande, 2000). De inhoudsfunctie houdt in dat studenten leren met verschillende programma's en dergelijke te werken die belangrijk zijn in de uitoefening van het vak, bijvoorbeeld het leren gebruiken van SPSS, SSCl, Word, spreadsheets, zoeksystemen, PowerPoint, enz. Het gaat hierbij dus om kennis en vaardigheden op het gebied van ICTtoepassingen in het vakgebied zelf. De informatiefunctie houdt in dat studenten met behulp van ICT allerlei informatie snel en gemakkelijk kunnen opsporen, bijvoorbeeld collegesheets, studiemateriaal, roosters, tijdschriften, databanken, en dergelijke die via Internet bereikbaar zijn. De communicatiefunctie van ICT heeft betrekking op het vergemakkelijken van de communicatie tussen docenten en studenten, en tussen studenten (en docenten) onderling, bijvoorbeeld via e-mail, het onderhouden van een gezamenlijke discussie op een studiesite, enzovoort. ICT kan ook een diagnostische functie vervullen, waarbij studenten bijvoorbeeld op advies van de studieadviseur een vragenlijst over studieproblemen op de computer invullen en direct feedback krijgen op hun antwoorden. Een stap verder is de leerfunctie, waarbij ICT door een groep studenten wordt gebruikt om samenwerkend leren op afstand mogelijk te maken en te ondersteunen: samen kennis te genereren of aan een gezamenlijk leerproduct (zoals een projectverslag) te werken (bijv. electronische leeromgevingen als Polaris, CSCL, Knowledge Forum). En tenslotte kan ICT ook worden gebruikt om leerresultaten te toetsen en competentieontwikkeling te documenteren (toetsfunctie, bijvoorbeeld elektronisch toetsen of digitaal portfolio). 


\section{Onderwijsontwikkeling en onderwijsresearch}

"Van de aan te stellen hoogleraar mag een expliciete en richtinggevende taak worden verwacht in het proces van onderwijsvernieuwing aan de Faculteit der Gezondheidswetenschappen". Dit is een citaat uit het structuurrapport hoogleraar Onderwijskunde, dat ten grondslag lag aan mijn benoeming hier, en waarin het profiel en de taken van de nieuwe hoogleraar werden omschreven. Uit wat ik tot nu toe heb gezegd mag blijken dat ik mij de komende jaren graag voor deze taak wil inzetten. En er komt de komende jaren nogal wat op de faculteit af. De Bachelor-Master structuuir, de inhaalslag met ICT in het onderwijs, nieuwe onderwijsvormen, nieuwe toetsvormen, de studie life sciences in de Transnationale Universiteit Limburg, enzovoort. Het afgelopen jaar heb ik, op verzoek van het Opleidingsbestuur van de Faculteit der Gezondheidswetenschappen, projectvoorstellen uitgewerkt op het gebied van zelfsturende studiegroepen, projectonderwijs, en flexibilisering van het onderwijsaanbod aan studenten door middel van bijvoorbeeld video en werkcolleges. In samenwerking met docenten van de Faculteit en medewerkers van het Maastricht McLuhan Instituut werken we aan de ontwikkeling en implementatie van een elektronische leeromgeving voor studenten. Hiermee moet onder meer het (samenwerkend) leerproces van deeltijdstudenten die in heel Nederland wonen, worden vergemakkelijkt. Wat betreft nieuwe vormen van toetsing experimenteren we met (digitale) portfolio's. Al deze projecten zijn reeds in hun uitvoerende fase.

Ook op het gebied van docentprofessionalisering is een nieuw traject uitgewerkt, te starten in 2001, zowel met een nieuw inhoudelijk aanbod met het oog op de onderwijsinnovaties als met een meer individueel gerichte coachingsaanpak. Met de studieadviseurs en andere medewerkers van onze eigen faculteit, de Faculteit der Economische Wetenschappen en Bedrijfskunde, de Faculteit der Cultuurwetenschappen en de Dienst Studentenzaken werken we samen aan de ontwikkeling van een integraal systeem van studieloopbaanbegeleiding. Daarnaast zullen de komende jaren onderwijsinnovaties nodig zijn op het gebied van curriculumherziening als gevolg van de Bachelor-Master structuur. Centraal bij dit alles staat het ontwikkelen van nieuwe vormen van studentgericht onderwijs die veeleisend zijn naar de student toe, en die meeveranderen met de toenemende zelfstandigheid en samenwerking waartoe studenten in staat zijn. 
De onderzoekslijn die ik de afgelopen jaren heb ingezet naar 'student learning in higher education', zal ik hier in Maastricht krachtig voortzetten. In samenwerking met collega's van de capaciteitsgroep en daarbuiten zal ik onderzoek initiëren en verrichten naar de leerprocessen, diepgang van verwerking, wijze van sturing, studiegedrag en studietijdbesteding van studenten in verschillende fasen van de studie, de factoren die daarop van invloed zijn, en de consequenties daarvan voor de inrichting van het onderwijs. In aansluiting daarop zullen ook de leerprocessen van docenten onderwerp van studie zijn, en de consequenties daarvan voor docentprofessionalisering. In samenwerking met docenten en studenten van de Faculteit zullen we nieuwe vormen van studentgericht onderwijs ontwikkelen voor verschillende fasen van de studie die passen in de onderwijsvisie zoals hiervoor geschetst. Hierbij zal ook nieuwe ICT worden betrokken. We zullen deze nieuwe onderwijsvormen in experimenten uitproberen en onderzoeken op hun effecten op studiegedrag, zelfstandigheid en studieresultaten van studenten en op de waardering die ze van studenten en docenten krijgen.

\section{Woorden van dank}

Aan het einde gekomen van deze oratie wil ik graag enkele mensen in het bijzonder bedanken.

Op de eerste plaats wil ik het College van Bestuur en het Bestuur van de Faculteit der Gezondheidswetenschappen bedanken voor het in mij gestelde vertrouwen.

Ook wil ik graag mij dank uitspreken aan de collega's van de Capaciteitsgroep Onderwijsontwikkeling en Onderwijsresearch van de Universiteit Maastricht, met name in de persoon van voorzitter Cees van der Vleuten, voor de prettige inwerkperiode. Ik heb aan den lijve mogen ondervinden wat samenwerkend leren betekent. Ook alle collega's van de Faculteit der Gezondheidswetenschappen en van andere faculteiten en geledingen van de Universiteit Maastricht die ik in deze periode heb leren kennen wil ik bedanken voor de plezierige inwerktijd.

Mijn promotoren Len de Klerk en RobertJan Simons wil ik bedanken voor het feit dat ze mij in de wereld van het onderwijspsychologisch onderzoek hebben ingewijd. Jullie gaven leiding aan het onderzoek van de toenmalige sectie Onderwijs- en Opleidingspsychologie van de Katholieke Universiteit Brabant te Tilburg. De onderzoeksgroep die er zat was een ideale voedingsbodem voor de onderzoeken naar leerstijlen en sturen van leerprocessen die ik daar 
heb uitgevoerd en die de basis waren voor mijn proefschrift. De toenmalige meester-gezel verhouding is inmiddels overgegaan in goede collegiale vriendschap.

Mijn promoti Gonny Schellings, Clara Ajisuksmo, Yvonne Vermetten, en binnenkort Anneke Zanting en Ida Oosterheert wil ik bedanken voor het wederzijdse leren. Ik hoop dat jullie wat van mij hebben opgestoken, maar ik heb zeker ook veel opgestoken van de begeleidingsgesprekken die we hebben gevoerd en de inzichten die jullie onderzoeken hebben opgeleverd. Mogen werken met zulke getalenteerde promovendi heb ik als een van de plezierigste dingen van het werken aan de universiteit ervaren.

Graag wil ik ook bedanken de oud-collega's van de plaatsen waar ik voorheen heb gewerkt. Met name wil ik noemen Nico Verloop en Douwe Beijaard van het ICLON van de Universiteit Leiden voor de bijzonder leerzame en vriendschappelijke manier van samenwerken in de hectische omgeving van de lerarenopleiding. Hans Lodewijks en Johan van der Sanden voor de goede samenwerking in de Tilburgse periode in onderzoek en onderwijs. Bernadette van Hout-Wolters en Geert ten Dam voor het vertrouwen en de samenwerking in de tijd dat we collega's waren op het Instituut voor de Lerarenopleiding van de Universiteit van Amsterdam. Alle plekken hadden hun eigen sfeer, cultuur en vriendschap, hun eigen krachtige leeromgeving. Ik raakte er niet uitgeleerd!

Mijn ouders, beiden helaas al jaren overleden, die al hun kinderen 'lieten leren' in een tijd en omgeving waarin dat beslist niet gebruikelijk was.

Margaret, Dorith en Paul, ik geniet altijd weer enorm van de vrije weekenden, avonden en vakanties met jullie. Die zal ik nooit opgeven, hoe druk het werk ook is!

En tenslotte wil ik $u$ allen bedanken voor de moeite die $u$ heeft genomen om hier aanwezig te zijn. Ik waardeer dat bijzonder.

Ik heb gezegd. 


\section{Referenties}

Ajisuksmo, C.R.P., \& Vermunt, J.D. (1999). Learning styles and selfregulation of learning at university: an Indonesian study. Asia Pacific Joumal of Education, 19(2), 45-59.

Bergen, T.C.M. (1996). Docenten scholen docenten. Inaugurale rede, Katholieke Universiteit Nijmegen.

Bolhuis, S., \& Kluvers, C. (1998). Procesgericht onderwijs. In J. Vermunt \& L. Verschaffel (Red.), Onderwijzen van kennis en vaardigheden (pp. 87-106). Onderwijskundig Lexicon Editie III. Alphen aan den Rijn: Samsom Tjeenk Willink.

Boud, D. (1999, August). Is problem-based leaming sufficiently robust to meet the new challenges of professional work? Paper presented at the 8th Conference of the European Association of Research on Learning and Instruction, Göteborg, Sweden.

Bouhuys, P. (2000, September). Developing the leamer's potential to leam. Keynote address given at the international conference on 'Innovations in higher education 2000', Helsinki, Finland.

Collins, B., \& Van der Wende, M. (1999). Het gebruik van ICT in het hoger onderwijs: een internationale verkenning. Tijdschrift voor Hoger Onderwijs, 17(3).

Elsevier (2000, Oktober). Special De beste studies. Amsterdam: Smit.

Haitink, A. (1996). Teamleren in de lerarenopleiding. In J. Kaldeway, J. Haenen, S. Wils \& G. Westhoff (Red.), Leren leren in didactisch perspectief (pp. 303-321). Groningen: Wolters-Noordhoff.

Hamaker, C. (2000). Didactische werkvormen. In G. ten Dam, H. van Hout, C. Terlouw \& J. Willems (Red.), Onderwijskunde hoger onderwijs - handboek voor docenten (pp. 74-99). Assen: van Gorcum.

Kirschner, P. (2000). The inevitable duality of higher education: cooperative higher education. Inaugurele rede, Universiteit Maastricht.

Korthagen, F.A.J. (1998). Leraren leren leren. Realistisch opleidingsondenwijs, geinspireerd door Ph. A. Kohnstamm. Inaugurale rede, Universiteit van Amsterdam.

Kuipers, H. (2000). Het PGO is aan vernieuwing toe. Discussie notitie (versie 4-10-2000). Universiteit Maastricht: Faculteit der Gezondheidswetenschappen. 
Machiels, M., \& Van Baak, M. (2000). Evaluatie Blok 4.1.Q Geneesmiddelen en prestatie. Een combinatie van $P G O$ en projectondenwijs. Universiteit Maastricht, Faculteit der Gezondheidswetenschappen.

Marton, F. (1999, August). Variatio est mater studiorum. Opening address given at the 8th Conference of the European Association of Research on Learning and Instruction, Göteborg, Sweden.

Mirande, M. (2000). Opleiden met informatie- en communicatietechnologie. In G. ten Dam, $H$. van Hout, C. Terlouw \& J. Willems (Red.), Ondenwiskunde hoger onderwijs - handboek voor docenten (pp. 201-216). Assen: van Gorcum.

Nieminen, J., \& Pruuki, L. (2000, September). How to support selfregulated learning? A report on an experimental course applications of the PBL-method. Paper presented at the international conference on 'Innovations in higher education 2000', Helsinki, Finland.

Oosterheert, I.E., \& Vermunt, J.D. (in press). Individual differences in learning to teach - relating cognition, regulation and affect. Learning and Instruction.

Ramsden, P. (1992). Learning to teach in higher education. London: Routledge.

Schellings, G.L.M., Van Hout-Wolters, B.H.A.M., \& Vermunt, J.D. (1996). Individual differences in adapting to three different tasks of selecting information from texts. Contemporary Educational Psychology, 21, 423-446.

Simons, P.R.J. (1997). From romanticism to practice in learning. Lifelong learning in Europe, 1, 8-15.

Simons, R.J., Van der Linden, J., \& Duffy, T. (2000). New learning: Three ways to learn in a new balance. In R.J. Simons, J. van der Linden \& T. Duffy (Eds.), New Learning (pp. 1-20). Dordrecht: Kluwer Academic.

Schmidt, H.G., \& Moust, J.H.C. (1998). Probleemgestuurd onderwijs: Praktijk en theorie. Groningen: Wolters-Noordhoff.

Steenkamp, F., Maljaars, W., \& Blankesteijn, E. (2000) (Red.), Keuzegids hoger onderwijs Editie 2000-2001. Amsterdam: Balans.

Ten Cate, Th. J. (1999). Valide medisch onderwijs. Inaugurele rede, Universiteit Utrecht.

Tigchelaar, A., \& Melief, K. (1997). Collegiaal ondersteund leren in de lio-stage: lio's leren elkaar te begeleiden. VELON - Tijdschrift voor Lerarenopleiders, 18(3), 27-32.

Van Berkel, H.J.M., Nuy, H.J.P., \& Geerligs, T. (1995). The influence of progress tests and block tests on study behaviour. Instructional Science, 22, 317-333. 
Van den Bosch, H., Gerritsen, R., \& Meijssen, L. (1998, August). The development of academic competence by merging problem based and project oriented learning. Paper presented at the joint meeting of the EARLI-SIGs 'Higher Education' and 'Teaching and Teacher Education' on Educating expert minds for the $21^{\text {st }}$ century, Leiden, The Netherlands.

Van Eekelen, I., Boshuizen, H., \& Vermunt, J. (submitted). Learning at work: Examples from the teaching profession. Manuscript submitted for publication.

Van Loosbroek, L., \& Willems, J. (2000). Opdrachten die stimuleren tot zelfstandig leren. In G. ten Dam, H. van Hout, C. Terlouw \& J. Willems (Red.), Onderwijskunde hoger onderwijs - handboek voor docenten (pp. 56-73). Assen: van Gorcum.

Van Tartwijk, J., \& Wubbels, Th. (2000). Evalueren van leervorderingen met behulp van portfolio's. In R.J. Bosker (Red.), Evalueren in het onderwijs (pp. 41-58). Onderwijskundig Lexicon Editie III. Alphen aan den Rijn: Samsom.

Van Woerden, W. (2000). De ontwikkeling van activerend onderwijs: Probleemgestuurd leren en projectonderwijs. In G. ten Dam, H. van Hout, C. Terlouw \& J. Willems (Red.), Onderwijskunde hoger onderwijs - handboek voor docenten (pp. 217-244). Assen: van Gorcum.

Vermetten, Y.J., Lodewijks, H.G., \& Vermunt, J.D. (1999). Consistency and variability of learning strategies in different university courses. Higher Education, 37, 1-21.

Vermunt, J.D. (1996). Metacognitive, cognitive and affective aspects of learning styles and strategies: a phenomenographic analysis. Higher Education, 31, 25-50.

Vermunt, J.D. (1998). The regulation of constructive learning processes. British Journal of Educational Psychology, 68, 149-171.

Vermunt, J., \& Lowyck, J. (2000). Leeractiviteiten en procesgericht onderwijs. In G. ten Dam, H. van Hout, C. Terlouw \& J. Willems (Red.), Onderwijskunde hoger ondenwijs - handboek voor docenten (pp. 30-55). Assen: van Gorcum.

Vermunt, J.D., \& Verloop, N. (1999). Congruence and friction between learning and teaching. Learning and Instruction, 9, 257-280.

Vermunt, J.D., \& Verloop, N. (2000). Dissonance in students' regulation of learning processes. European Joumal of Psychology of Education, $15,75-89$.

Vermunt, J., \& Verschaffel, L. (2000). Process-oriented teaching. In R.J. Simons, J. van der Linden \& T. Duffy (Eds.), New Learning (pp. 209225). Dordrecht: Kluwer Academic. 
Volet, S., McGill, T., \& Pears, H. (1995). Implementing process-based instruction in regular university teaching: Conceptual, methodological and practical issues. European Journal of Psychology of Education, $10,385-400$.

Westerterp, M., et al. (2000). Electronische Project Omgeving (EPO) voor Gezondheidswetenschappen. Activiteit 1: Onderwijskundig ontwerp (versie 30-10-2000). Universiteit Maastricht: Faculteit der Gezondheidswetenschappen \& Maastricht McLuhan Institute.

Zanting, A., Verloop, N., \& Vermunt, J.D. (in press). Student teachers' beliefs about mentoring and learning during practice teaching. British Journal of Educational Psychology. 